\title{
Silicified Eocene molluscs from the Lower Murchison district, Southern Carnarvon Basin, Western Australia
}

\author{
Thomas A. Darragh' and George W. Kendrick ${ }^{2,3}$ \\ 'Department of Invertebrate Palaeontology, Museum Victoria, P.O. Box 666, Melboume, \\ Victoria 3001, Australia. Email: tdarraghomuseum.vic.gov.au \\ 2Department of Earth and Planetary Sciences, Western Australian Museum, Locked Bag 49, \\ Welshpool D.C., Western Australia 6986, Australia. \\ 'School of Earth and Geographical Sciences, The University of Western Australia, \\ 35 Stirling Highway, Crawley, Western Australia 6009, Australia.
}

\begin{abstract}
Silicified Middle to Late Eocene shallow water sandstones outcropping in the Lower Murchison District near Kalbarri township contain a silicified fossil fauna including foraminifera, sponges, bryozoans, solitary corals, brachiopods, echinoids and molluscs. The known molluscan fauna consists of 51 species, comprising 2 cephalopods, 14 bivalves, 1 scaphopod and 34 gastropods. Of these taxa three are newly described, Cerithium wilya, Zeacolpus bartoni, and Lyria lamellatoplicata. 25 of these molluscs are identical to or closely comparable with taxa from the southern Australian Eocene. The occurrence of this fauna extends the Southeast Australian Province during the Eocene from southwest Western Australia along the west coast north to at least $27^{\circ}$ present day south latitude; consequently the province is here renamed the Southern Australian Province.
\end{abstract}

Keywords: siliceous fossils, Eocene, Kalbarri, molluscs, new taxa, Carnarvon Basin, biogeography, Southern Australian Province.

\section{INTRODUCTION}

Eocene marine molluscan assemblages from coastal sedimentary basins in southern Australia have been reviewed recently by Darragh and Kendrick (2000, Table 1, Figure 1), with descriptions of new species and other records from the Bass, Port Phillip, Otway, Murray, St Vincent and Bremer Basins. In contrast, Eocene molluscs from the Carnarvon Basin (Giralia Calcarenite, Merlinleigh Sandstone) have received little attention and, to the time of writing, remain largely unknown. The recent discovery in the lower Murchison District near Kalbarri township of silicified, marine Eocene sediments (Haig and Mory 2003), containing a diversity of well-preserved molluscan material, presents an opportunity to extend the study of these groups, erstwhile essentially southern in distribution, westward and northward into the Southern Carnarvon Basin.

The Kalbarri deposit, source of the present study material, was discovered by $\mathrm{Mr}$ David Barton of Kalbarri (see Material, below). Situated within the Kalbarri National Park, the locality lies some 19.5 $\mathrm{km}$ ESE from Kalbarri townsite, striking south and west for about $2 \mathrm{~km}$ near Junga Dam, south of the Ajana-Kalbarri road. A central map reference on the Kalbarri 1:100,000 topographic sheet (1742) is 397260 , at an elevation close to $220 \mathrm{~m}$ above AHD.
The source deposit, a pallid to ferruginous silicified sandstone, forms a weakly defined, low breakaway trending N-S and sloping gently westward. Its lithology and stratigraphic relationships have been described by Haig and Mory (2003).

Invertebrate marine fossils, predominantly sponges and invariably silicified, lie on the weathered surface of and downslope from the breakaway. Eocene fossils collected to date from this source comprise foraminifers, sponges, bryozoans, solitary corals, brachiopods, echinoids and mollusc shells, the latter comprising a scaphopod, bivalves, gastropods and nautiloids. Further down slope occur fragments of pale, silicified porcellanite and belemnite guards (Peratobolus sp.), derived from the unconformably underlying Aptian Windalia Radiolarite (Haig and Mory 2003: 107).

\section{MATERIAL}

Three separate collections, all from the same source area, constitute the study material.

1. Collection of Mr David Barton, acquired over the period 2000-2001 and presented to the Western Australian Museum in 2005. The Barton Collection is registered in the Museum's catalogue numerical sequence 05.182 to 05.212 inclusive. 
2. Collection of K.J., K.A. and J.P. McNamara and S.P. Radford, during April 2004 and bearing catalogue numerical sequence 04.206 to 04.240 inclusive.

3. Collection of T.A. Darragh and G.W. Kendrick, October 2005 and catalogue numerical sequence 06.178-06.191, 07.1-07.30; also Museum Victoria numbers NMV P313978-P313989, P314038314040.

4. Nautiloids collected by D.W. Haig, School of Earth and Geographical Sciences, University of Western Australia, UWA 130880-1.

The specimens for this study are lodged in the following institutions: Museum Victoria, Melbourne (NMV); University of Western Australia, Nedlands (UWA); Western Australian Museum, Perth (WAM).

\section{AGE AND CORRELATION}

Planktonic foraminiferal determinations presented by Haig and Mory (2003) have established an age for the Kalbarri deposit within the interval P13-16 (Pzonation of Berggren and Miller 1988), BartonianPriabonian (= Johannian-Aldingan Australian Stages) of the Middle to Late Eocene. The absence of tropical and subtropical species of foraminifers suggests a cooling trend over this interval, comparable with that noted for southern Australian waters by McGowran et al. (2000).

Mollusc species from the Kalbarri Eocene show substantial direct affinities with those of the Bremer and other coastal basins of southern Australia, the assemblage overall being essentially temperate in character, though including some possible tropical or subtropical elements. Thus, of the 51 mollusc species recognised below in the study material, 25 are identical to or closely comparable with taxa from the southern Australian Eocene (Darragh and Kendrick 2000, Table 1).

\section{COMPARISON WITH THE MERLINLEIGH SANDSTONE}

The Middle to Late Eocene Merlinleigh Sandstone (Cockbain 1981) comprises thin (to $15 \mathrm{~m}$ ) erosional remnants of a transgressive, shallow water, near shore deposit, located along the western flank of the Kennedy Range, eastern Central Carnarvon Basin and some 350-400 km NNE from the Kalbarri deposit. The Merlinleigh Sandstone comprises mainly quartz sandstone with minor siltstone and conglomerate. Fossil material, invariably silicified, occurs as surface float below an erosion scarp and comprises foraminifera, colonial corals, bryozoans, hydrozoans, molluscs, fossil wood (some teredinebored) and other terrestrial plant material (Condon 1968, McNamara and Scott 1983, Haig and Mory 2003).
Other than the nautiloid Aturia clarkei Teichert (Teichert 1944), molluscs from the Merlinleigh Sandstone have thus far remained unrecorded. We here list (Table 2) provisional determinations of these from the collections of Museum Victoria and the Western Australian Museum, pending more detailed consideration in a future paper. None of these taxa seems to have affinity with those of the Eocene faunas of either southern Australia or Kalbarri. Haig et al. (1993) considered the Merlinleigh Sandstone and Giralia Calcarenite to be probably coeval and located within zones P11 - P13 of the Middle Eocene and hence older than the present Kalbarri deposit. This, together with marked facies contrasts and latitudinal discrepancies are consistent with the substantial differences here noted between the Kalbarri and Merlinleigh mollusc assemblages.

\section{FAUNAL CONTRASTS AND DEPOSITIONAL ENVIRONMENTS}

Mollusca from the Merlinleigh Sandstone, compared with those from the Kalbarri Eocene, differ mostly in generic identity and also in being much larger and more robust. No species of the genus Periglypta Jukes-Brown, 1914 has been recorded from any Tertiary deposit in southern Australia nor is it present at Kalbarri. Corals from the two sources contrast strongly; those from Merlinleigh being colonial in character, common and robust whereas in the Kalbarri Eocene, corals are rare and to date are confined to specimens of the solitary, azooxanthellate genus Flabellum Lesson. Modern records of this genus from southern and Western Australia (Cairns and Parker 1992, Cairns 1998) are associated with water depths usually in excess of $100 \mathrm{~m}$ and indicate habitats of the middle to outer continental shelf and slope. Sponges, unknown from the Merlinleigh Sandstone, are common and conspicuous at Kalbarri, consistent with a deeper water, perhaps middle shelf environment of deposition, although the rolled and broken nature of all the fossils and the coarse sediment in which they are found may indicate that the material had been washed into shallower water.

Post-mortem transportation of the study material is supported by the markedly disproportionate numerical representation of the various species. Thus Zeacolpus bartoni sp. nov. with 577 specimens and Cerithium wilya sp. nov. (53 specimens) contrast with 35 other species in the assemblage, represented by only one or two specimens.

\section{PALAEOGEOGRAPHY}

The Southeastern Australian Province supports a temperate marine mollusc fauna, hitherto recognised in Eocene time as extending along the 
Table 1 Mollusc determinations in the study material from Eocene beds, Kalbarri.

\section{CEPHALOPODA \\ 1. Eutrephoceras sp. \\ 2. Aturia clarkei Teichert}

\section{BIVALVIA}

3. Sarepta planiuscula (Tate)

4. Limopsis chapmani Singleton

5. Tucetona lenticularis (Tate)

6. Solamen (Exosipema) sp. aff. S.(E) globularis (Tate)

7. Vulsella sp. cf. V. laevigata Tate

8. cf. Talochlamys eyrei (Tate)

9. Plicacesta? sp.

10. Chamasp

11. Epicodakiasp.

12. Glyptoactis (Fasciculicardia) sp. cf. G.(F.) latissima (Tate)

13. Pratulum hemimeris (Tate)

14. Dosina (Dosina) multilamellata (Tate)

15. cf. Fossacallista tatei (Cossmann)

16. Caryocorbula pixidata (Tate)

\section{SCAPHOPODA}

17. Dentalium (Fissidentalium) mawsoni Ludbrook

\section{GASTROPODA}

18. Emarginula sp.

19. Micrelenchus (Plumbelenchus) armulatus Darragh \& Kendrick

20. Calliostoma sp. aff. C. (Fautor) numapum Darragh \& Kendrick

21. Cerithium wilya sp. nov.

22. Zeacolpus bartonisp. nov.

23. Tenagodus sp.

24. Xenophora sp. aff, $X$ tatei Harris

25. Naticid sp.

26. Euspirocrommium sp.

27. Galeodea sp.

28. Notoseila sp.

29. Cerithiella sp.

30. Cirsotremasp. aff. C. pleiophylla Tate

31. Margineulima sp.

32. Turbinellid? sp.

33. Murexsulsp.

34. Brocchitas?sp.

35. Dennantia aldingensis (Tate)

36. Alcithoe (Waihaoia) pagodoides (Tate)

37. Notovoluta capitonica Darragh

38. Notopeplum protorhysum (Tate)

39. Lyria lamellatoplicatasp. nov.

40. Gemmolivasp. cf. G. adelaidae (Tate)

41. Gracilispirasp.cf. G. ligata (Tate)

42. Cochlespirasp

43. Parasyngenochilus sp. of. P. angustior long

44. Germmula?sp.

45. Mauidrillia sp. cf. M. aldingensis Powell

46. Marginellasp. A

47. Marginella sp. B

48. Mitrid sp. A

49. Mitrid sp. B

50. Conus? sp.

51. Conorbis sp. 
Table 2 Molluscs from the Merlinleigh Sandstone in the collections of Museum Victoria and the Western Australian Museum.

Cephalopod

1. Aturia clarkei Teichert

Bivalves

2. Cucullaea sp.

3. Glycymeris sp.

4. Spondylus sp.

5. Chama sp.

6. Glans? sp.

7. Periglyptasp.

8. Dosina (Hina) sp.

9. Dosinia (Austrodosinia) sp.

Gastropod

10. Tugali? sp.

11. Turbosp.

south coast of Australia from the Gippsland Basin in the east to the Bremer Basin in the west (Darragh 1985, figure 3). The Austral Indo-Pacific Province, in essence an extension of the tropical Indo-Pacific Province, in Eocene time was thought to be confined to the Carnarvon Basin on the west coast of Australia. The results of the current work show this to be so, but in addition, that the Southeastern Australian Province extended at least to the southern part of the Southern Carnarvon Basin as far north as approximately present day $27^{\circ}$ south latitude. The Province may have extended further north, but if so, any evidence for this has probably been removed by erosion.

Of the molluscs present in the Kalbarri fauna, all genera are typically represented in the Southeastern Australian Province. All the bivalve and scaphopod genera are represented in the Eocene. Most of the gastropod genera are also known from the Eocene, with the exception of Zeacolpus and Lyria, the taxon here referred as Turbinellid? sp. and possibly Notoseila and Cerithiella. Of the cephalopods, Aturia is represented in the Eocene, but in Australia, Eutrephoceras has hitherto only been recorded from the Paleocene and the Miocene.

Inclusion of the Bremer and southern Carnarvon Basins in the Southeastern Australian Province makes the name of the province inappropriate. Consequently the province is renamed here the Southern Australian Province.

\section{SYSTEMATIC PALAEONTOLOGY}

\section{Class Cephalopoda}

Family Nautilidae

Genus Eutrephoceras Hyatt, 1894

Eutrephoceras sp.

Figures 1.14, 1.24, 1.25
Nautiloid indet.: Haig and Mory, 2003: figures 3 S, T.

\section{Material examined}

Australia: Western Australia: Kalbarri National Park, ca. $19.5 \mathrm{~km}$ ESE. of Kalbarri: 18 specimens (WAM 05.202); 10 specimens (NMV P313985); 1 specimen (UWA 130881). Total 29 specimens.

\section{Description}

Shell broadly lenticular. Siphuncle small, situated close to venter and slightly offset to the right. Hyponomic sinus broad and shallow. Small umbilicus closed by callus, but visible on some specimens. Sculpture of fine, close-set equal spiral lirae visible on early whorls and beaded where crossed by growth lines.

\section{Dimensions}

WAM 05.202a

$\begin{array}{cc}\text { Height } & \text { Width } \\ 33 & 19 \\ 11 & 7.5\end{array}$

\section{Discussion}

All specimens are juveniles consisting of one or two whorls, with the possible exception of the largest specimen (figured), which seems to consist of two or possibly three whorls. Though poorly visible, the suture line appears to be straight. Most of the shells are infilled with silica and are transparent, but there is no sign of a siphuncle within the shell nor are there signs of chambers in the better preserved specimens, so no suture lines are visible. The sculpture preserved on some of the smaller specimens is very similar to that figured by Landman et al. (1983, figure 4a) on Eutrephoceras dekayi (Morton, 1834), Late Cretaceous, North America.

Eutrephoceras species have been recorded from the Paleocene of Victoria by Teichert (1947) and by McGowran (1959) from the Early and Middle Miocene of South Australia and from the Middle Miocene of Victoria. If the genus is correctly identified, this is the first record from the Eocene of Australia.

\section{Occurrence}

Southern Carnarvon Basin: unnamed sandstone, Middle-Late Eocene.

\section{Family Aturiidae}

\section{Genus Aturia Bronn, 1838}

Aturia clarkei Teichert, 1944

Figures 1.18, 1.19

Aturia clarkei Teichert, 1944: 79, plate 15, figures 14; plate 16, figures 1, 2; text figure 2.

Aturia sp. Haig and Mory 2003: figures 3, Q, R. 


\section{Material examined}

Australia: Western Australia: Kalbarri National Park, ca. $19.5 \mathrm{~km}$ ESE. of Kalbarri: 1 specimen (UWA 130880).

\section{Description}

Shell slightly flattened, but flanks originally slightly convex, of small size; no umbilicus; venter broadly rounded; growth lines not visible. Siphuncle large, partly obscured by matrix.

\section{Dimensions}

$\begin{array}{lcc}\text { UWA } 130880 & 31.8 & 13.3\end{array}$

\section{Discussion}

The saddle of the suture on the Kalbarri specimen seems rounded, rather than slightly flattened, as in specimens of Aturia clarkei from the type locality near the Merlinleigh homestead site in the Kennedy Range. This slight difference could be a result of difficulty in tracing accurately the suture on this particular specimen, or perhaps because of some intra-specific or ontogenic variation, the Kennedy Range specimens being much larger $(40->100 \mathrm{~mm})$.

\section{Occurrence}

Otway Basin: Clifton Formation, reworked specimens. St Vincent Basin: Tortachilla Limestone. Bremer Basin: Pallinup Formation. Southern Carnarvon Basin: Merlinleigh Sandstone (type); unnamed sandstone, Middle-Late Eocene.

\section{Class Bivalvia}

Family Sareptidae

Genus Sarepta A. Adams, 1860

Sarepta planiuscula (Tate, 1886)

Figure 1.4

Leda planiuscula Tate, 1886: 130, plate 5, figure 2.

Ovaleda planiuscula (Tate): Ludbrook 1961: 61, plate 3 , figures 3,4 .

Sarepta planiuscula (Tate): Darragh and Kendrick 2000: 18, 22, figure 21.

\section{Material examined}

Australia: Western Australia: Kalbarri National Park, ca. $19.5 \mathrm{~km}$ ESE. of Kalbarri: conjoined valves (WAM 06.179); 1 fragment (NMV P313980).

\section{Description}

The better of the two Kalbarri specimens is a small, roundly subquadrate, conjoined pair, of which the left valve is substantially intact, right valve somewhat corroded and pitted. Slightly produced and rounded posteriorly, umbo weakly inflated, beaks slightly projecting and anterior of centre. Sculpture (LV) of faint, commarginal growth striae, scarcely discernible on umbo. Internal characters and those of dorsal margin concealed (described by Ludbrook 1961 from the type material).

\section{Dimensions}

$\begin{array}{cccc} & \text { Length } & \text { Height } & \text { Inflation } \\ \text { WAM 06.179 (pair) } & 5.4 & 4.1 & 2.3\end{array}$

\section{Discussion}

The present specimens compare well with others from the Pallinup Formation and from the type locality. The species combines a wide distribution with rarity in collections.

\section{Occurrence}

Otway Basin: Glen Aire Clay, Oligocene. St Vincent Basin: "Adelaide Bore", Kent Town (type), Blanche Point Formation, Late Eocene. Bremer Basin: North Walpole, Pallinup Formation, Late Eocene. Southern Carnarvon Basin: unnamed sandstone, Middle-Late Eocene.

\section{Family Limopsidae}

\section{Genus Limopsis Sassi, 1827}

\section{Limopsis chapmani Singleton, 1932 \\ Figure 1.21}

Limopsis chapmani Singleton, 1932: 296-299, plate 24, figures 12-14, plate 25, figure 16.

Limopsis (Limopsis) chapmani (Singleton): Darragh and Kendrick, 1980: 13, figures 2 O-R; Darragh and Kendrick 2000: 24.

\section{Material examined}

Australia: Western Australia: Kalbarri National Park, ca. 19.5 km ESE. of Kalbarri: conjoined valves (WAM 06.181).

\section{Description}

Conjoined valves, small for the species, RV somewhat corroded dorsally, LV substantially intact; obliquely sub-ovate, slightly produced posteriorly, umbones slightly prosogyrate, beaks slightly projecting, dorsal margin partly obscured, probably straight and less than half shell length. Sculpture of weak, spaced, commarginal striae.

\section{Dimensions}

WAM 06.181

$\begin{array}{ccc}\text { Length } & \text { Height } & \text { Inflation } \\ 4.6 & 5.0 & 2.7\end{array}$

\section{Remarks}

The Kalbarri specimen, probably a juvenile, 

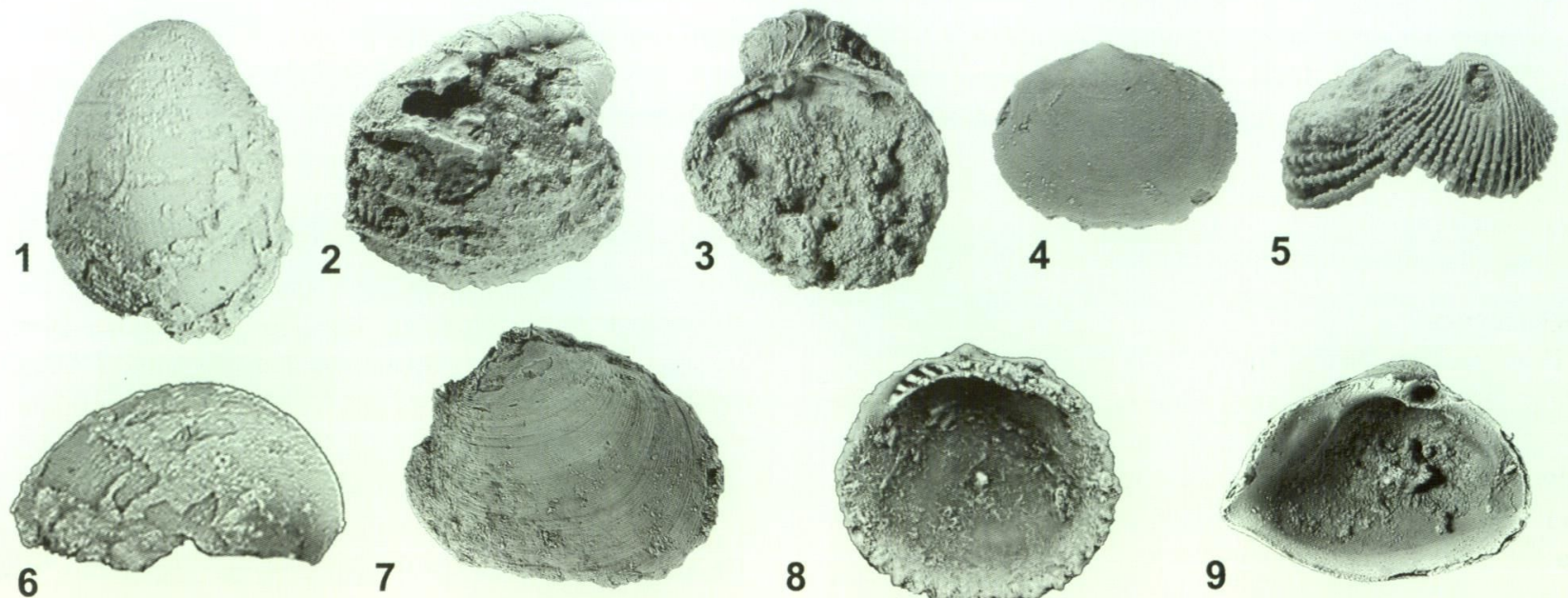

8
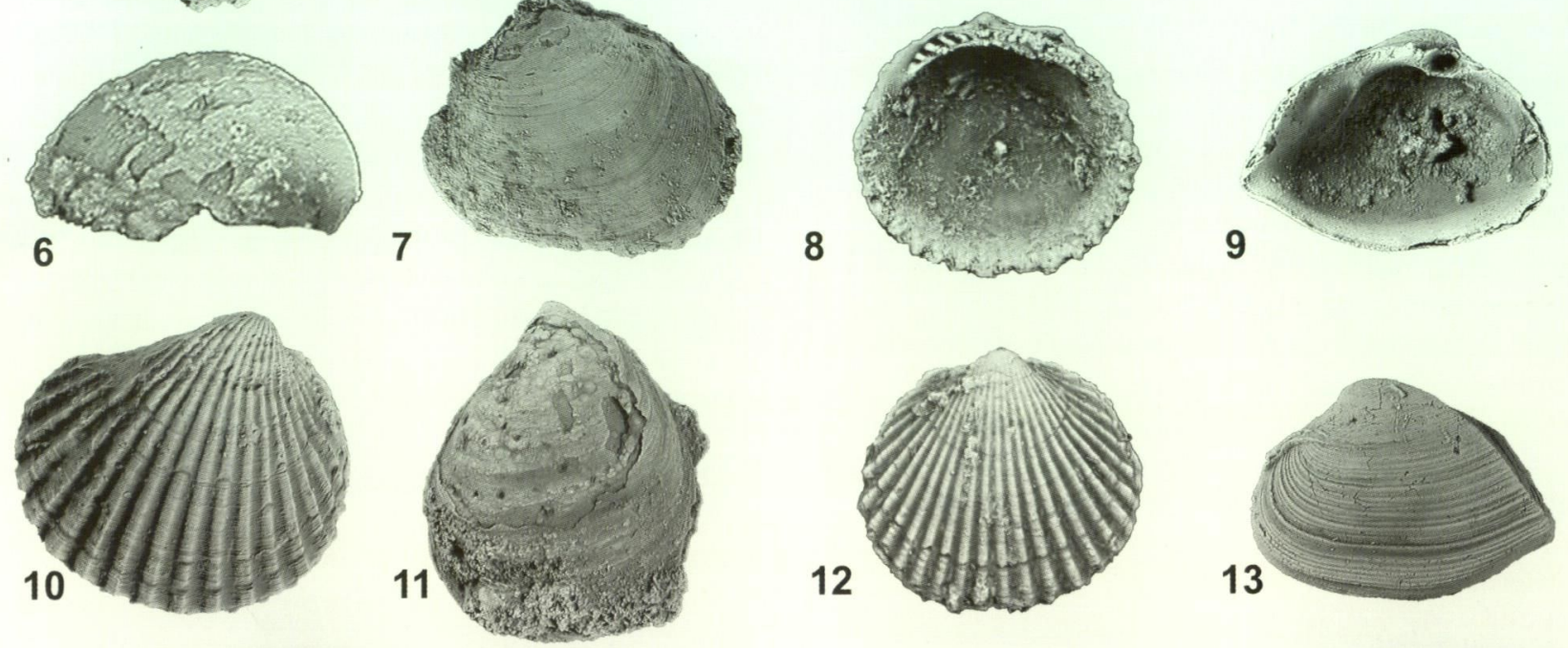

12
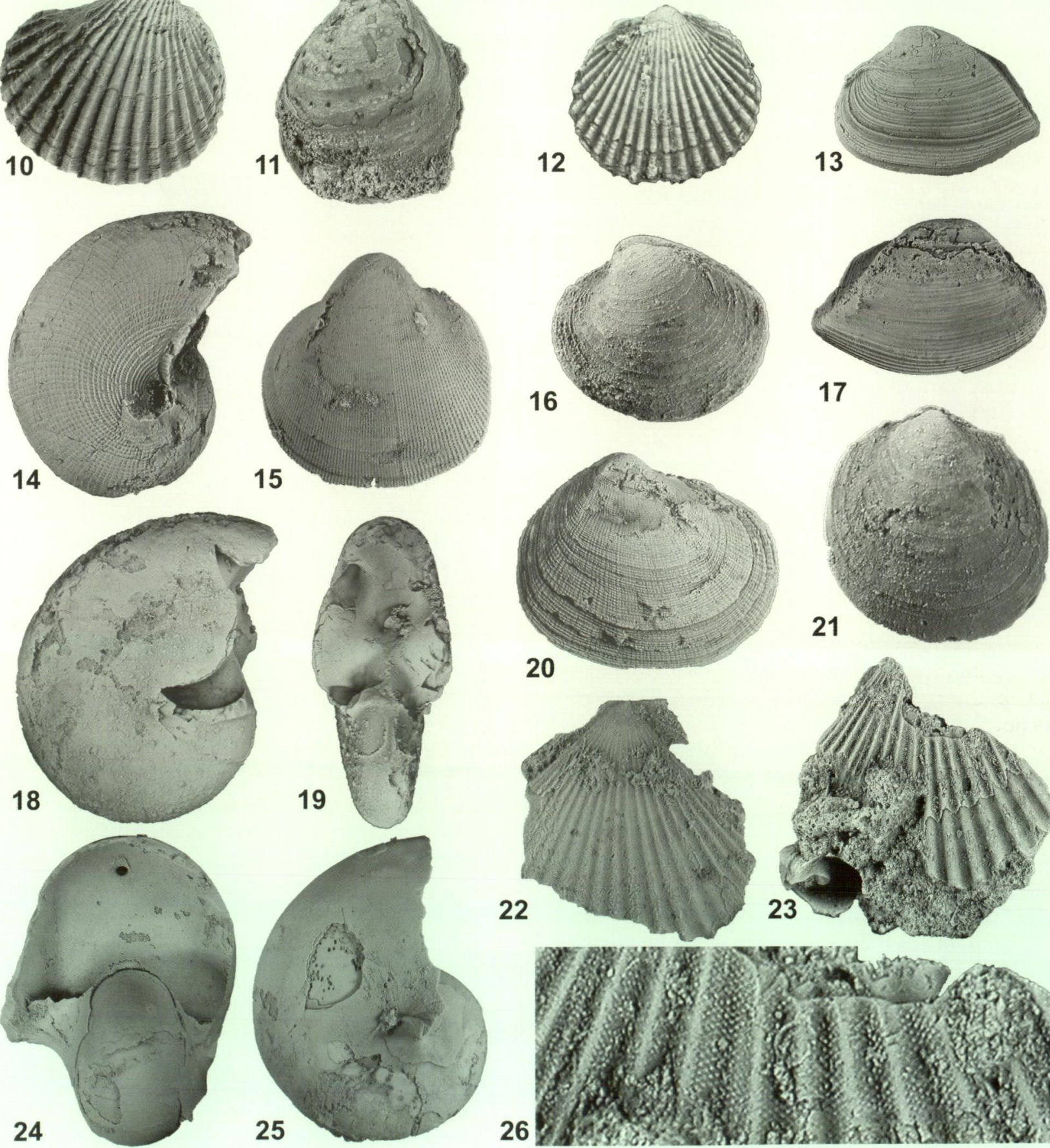

17

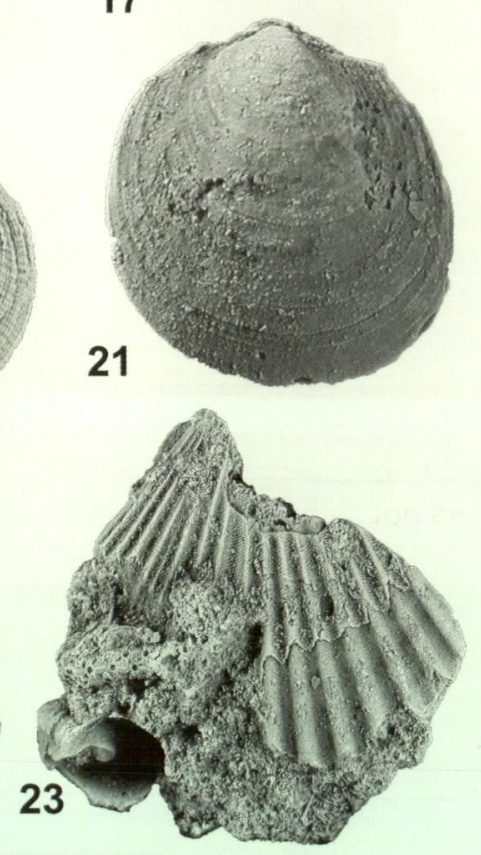

22
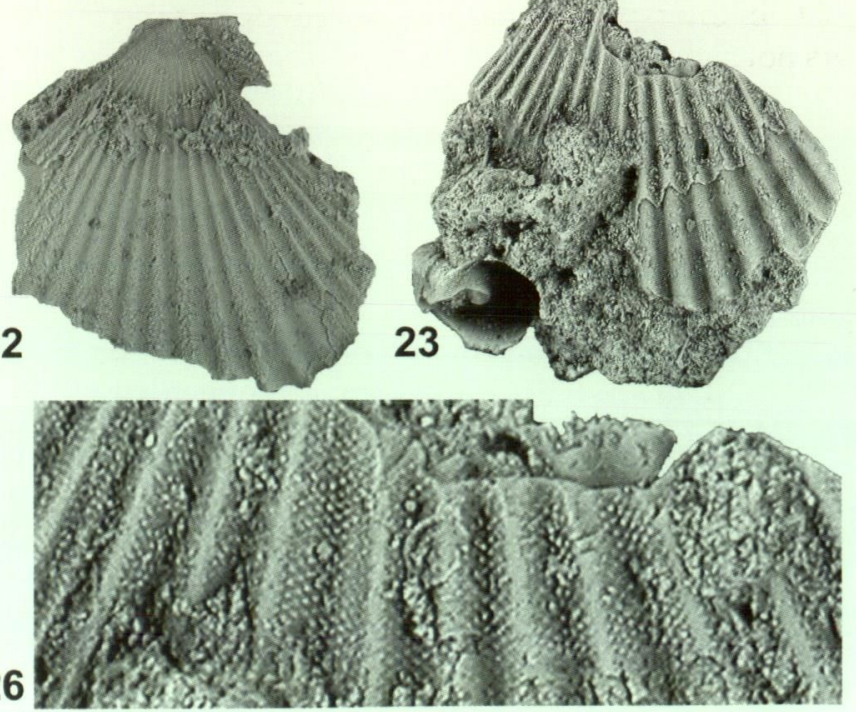
compares closely with conspecific material from Browns Creek and also North Walpole, where it occurs commonly and occasionally as a conjoined pair (Darragh and Kendrick 1980). Its abundance at the latter locality contrasts markedly with its rarity at Kalbarri.

\section{Occurrence}

Port Phillip Basin: Jan Juc Formation (type), Late Oligocene-Early Miocene. Otway Basin: Lower and upper Browns Creek Formation, Late Eocene. Lower Glen Aire Clay, Early Oligocene. St Vincent Basin: Blanche Point Formation, Late Eocene. Bremer Basin: Werillup Formation, Middle Eocene. Pallinup Formation, Late Eocene. Southern Carnarvon Basin: unnamed sandstone, Middle-Late Eocene.

\section{Family Glycymeridae}

\section{Genus Tucetona Iredale, 1931}

\section{Tucetona lenticularis (Tate, 1886) Figures 1.8, 1.12}

Pectunculus lenticularis Tate, 1886: 138, plate 11, figure 1.

Tucetona lenticularis (Tate): Darragh and Kendrick 2000: 24, figure 2J.

\section{Material examined}

Australia: Western Australia: Kalbarri National Park, ca. $19.5 \mathrm{~km}$ ESE. of Kalbarri: 2 specimens (WAM 04.206); 1 specimen (WAM 06.180); 2 specimens (NMV P313981). Total of four complete valves and one fragment.

\section{Description}

Single valves, all juveniles, some fragmentary. Orbicular, slightly longer than high, compressed, umbones low, orthogyrate, beaks small, located slightly posterior of centre, ligamental area narrow, costae numbering (present material) 21-26, about equal to interspaces, margins abraded, adductor scars not sighted.
Dimensions
WAM 04.206 (RV)
Length
Height
Inflation 6.3
5.9
1.7

\section{Remarks}

The limited material to hand from Kalbarri, from rib counts and other general characters, compares well with specimens of similar size from both Browns Creek and Pallinup Formations (WAM 05.29). Valve orientation of juveniles of this species requires care and preferably from access to the adductor muscle scars (Ludbrook 1965: 93). The specimen figured herein appears to be a RV, assuming that the beak is located slightly posterior of centre. Adult valves of this species may attain a length of up to $37 \mathrm{~mm}$.

\section{Occurrence}

Otway Basin: Browns Creek Formation, Late Eocene. Lower Glen Aire Clay, Early Oligocene. St Vincent Basin: South Maslin Sand, Middle Eocene. Blanche Point Formation (type), Late Eocene. Bremer Basin: Werrilup Formation, Middle Eocene. Pallinup Formation, Late Eocene. Southern Carnarvon Basin: unnamed sandstone, Middle-Late Eocene.

\section{Family Mytilidae}

Genus Solamen Iredale, 1924

Subgenus Exosiperna Iredale, 1929

Solamen (Exosiperna) sp. aff. globularis (Tate, 1886)

Figures 1.1, 1.6

Crenella globularis Tate, 1886: 126, plate 10, figure $3 a, b$.

\section{Material examined}

Australia: Western Australia: Kalbarri National Park, ca. $19.5 \mathrm{~km}$ ESE. of Kalbarri: 1 right valve (WAM 06.182).

Figure 1 Solamen (Exosiperna) sp. aff. S. (E.) globularis (Tate), 1, 6 WAM 06.182, RV x 8. Chama sp., 2, 3 WAM 06.187, RV external, internal x 3.7. Sarepta planiuscula (Tate), 4 WAM 06.179, LV x 5.0. Glyptoactis (Fasciculicardia) sp. cf. G. (F.) latissima (Tate), 5 WAM 06.188, LV x 4.4. cf. Fossacallista tatei (Cossmann), 7 WAM 06.189, LV x 3.0. Tucetona lenticularis (Tate), 8, 12 WAM 04.206, RV x 4.8. Caryocorbula pixidata (Tate), 9 WAM 06.190, LV internal x 3.9; 13 WAM 06.190, LV external x 3.9; 17 WAM 05.183 RV external x 3.9. Plicacesta? sp., 10 WAM 05.202, LV x 3.8. Vulsella sp. cf. V. laevigata Tate, 11 WAM 06.183, LV x 3.7. Eutrephoceras sp., 14 WAM 05.202b x 4.2; 24, 25 WAM 05.202a x 1.5. Pratulum hemimeris (Tate), 15 WAM 04.208, LV x 3.0. Dosina (Dosina) multilamellata (Tate), 16 WAM 04.209, LV x 5.7. Aturia clarkei Teichert, 18, 19 UWA $130880 \times 1.7$ (18), x 1.6 (19). Epicodakia sp., 20 WAM 05.182, RV x 4.0. Limopsis chapmani Singleton, 21 WAM 06.181, LV x 6.6. cf. Talochlamys eyrei (Tate), 22 WAM 06.184, RV x 2.8; 23 WAM 06.185, RV? x 2.6; 26 WAM 06.185, $\mathrm{RV} ? \times$ 9.6. 


\section{Description}

Small, higher than long, inflated, beak incurved, slightly anterior of centre. Sculpture mostly obscured by secondary silica but some very faint commarginal and finer, radial sculpture discernable in part.

$\begin{array}{lccc}\text { Dimensions } & & & \\ & \text { Length } & \text { Height } & \text { Inflation } \\ \text { WAM 06.182 } & 2.9 & 3.7 & 2.7\end{array}$

\section{Remarks}

The discovery of what may prove to be Tate's rather uncommon species at Kalbarri, hitherto known only from the Late Eocene of the St Vincent Basin, suggests a possible substantial extension of range for the species. The Kalbarri specimen is about half the size of Tate's type and is in part decorticated and also overlain by secondary silica; however traces of light, cancellate sculpture are discernible.

\section{Occurrence}

St Vincent Basin: Blanche Point Formation, Late Eocene (type). Southern Carnarvon Basin: unnamed sandstone, Middle-Late Eocene.

\section{Family Malleidae}

Genus Vulsella Röding, 1798

\section{Vulsella sp. cf. V.laevigata Tate, 1886}

Figure 1.11

Vulsella laevigata Tate, 1886: 122, plate 3, figure 3a, b; Darragh and Kendrick 1980: 15, figures 3D-H.

Material examined

Australia: Western Australia: Kalbarri National Park, ca. $19.5 \mathrm{~km}$ ESE. of Kalbarri: 1 left valve (WAM 06.183).

\section{Description}

Higher than long, moderately inflated, umbo elevated, beak projecting, opisthogyrate, margin posteriorly excavate below beak, slightly convex anteriorly. Sculpture part-corroded, part-obscured but some weak, spaced, commarginal costae visible. Internal characters obscured.

\section{Dimensions}

WAM 06.183, LV

$\begin{array}{ccc}\text { Length } & \text { Height } & \text { Inflation } \\ 8.0 \text { (est.) } & 9.5 & -\end{array}$

\section{Remarks}

The single valve to hand from Kalbarri appears to be of greater length relative to height than examples of Tate's species from the Pallinup Formation of
North Walpole and has a thicker shell than any known specimen from there. These apparent differences and their significance, if any, need to be clarified by the collection of further material from the present locality.

\section{Occurrence}

St Vincent Basin: Glauconitic limestone at the base of Witton Bluff, near mouth of the River Onkaparinga, South Australia. Tortachilla Limestone, Late. Eocene (type). Bremer Basin: Pallinup Formation, Late Eocene. Southern Carnarvon Basin: unnamed sandstone, Middle-Late Eocene.

\section{Family Pectinidae}

Genus Talochlamys Iredale, 1929

cf. Talochlamys eyrei (Tate, 1886)

Figures 1.22, 1.23, 1.26

Pecten eyrei Tate, 1886: 107, plate 8, figures 3a, b, 6 .

Talochlamys eyrei (Tate): Beu and Darragh 2001: 101-106, figures 31B, C, E, G, I; 32G; 33A-E; 34A-G.

\section{Material examined}

Australia: Western Australia: Kalbarri National Park, ca. $19.5 \mathrm{~km}$ ESE. of Kalbarri: 1 right valve, fragment (WAM 06.184); 1 right valve?, fragment (WAM 06.185). Total of two specimens.

\section{Description}

Two fragmentary, immature specimens are consistent with and probably referable to Tate's species. The better of the two retains portion of the anterior auricle and byssal notch. Shagreen sculpture is well developed on each but neither shows any trace of commarginal sculpture on the costae or elsewhere. So far as can be observed, the sculpture of these specimens corresponds to that of the peroni form of T.eyrei (Beu and Darragh 2001).

\section{Dimensions}

WAM 06.184

$\begin{array}{ccc}\text { Length } & \text { Height } & \text { Inflation } \\ \text { ca } 14 & - & -\end{array}$

\section{Remarks}

The genus and its fossil component from the Tertiary of southern Australia have been reviewed by Beu and Darragh (2001), with most occurrences from Victorian and South Australian sources. Additional to these are a few records from the Eucla (Eocene-Miocene) and Bremer (Eocene) Basins.

Talochlamys eyrei is a common and widely distributed species from the Aldingan to Longfordian variously in the St Vincent, Murray 
and Otway Basins. Confirmed records for the species from Western Australia are few and to date are confined to the Wilson Bluff and Abrakurrie Limestones of the Eucla Basin.

Two species of Talochlamys, approximately coeval with but distinct from the study material, are recorded from the Pallinup Formation of the Bremer Basin (Beu and Darragh 2001). Specimens are few and of inferior preservation. Clarification of their identities is subject to the collection of further, well-preserved material.

\section{Occurrence}

Southern Carnarvon Basin: unnamed sandstone, Middle-Late Eocene.

\section{Family Limidae}

\section{Genus Plicacesta Vokes, 1963}

\section{Plicacesta? sp. \\ Figure 1.10}

Material examined

Australia: Western Australia: Kalbarri National Park, ca. $19.5 \mathrm{~km}$ ESE. of Kalbarri: conjoined valves (WAM 06.186).

\section{Description}

Conjoined equal valves, obliquely sub-orbicular, slightly inflated, extended anteriorly. Posterior auricles very small, antero-dorsal area somewhat corroded, anterior gape obscured. Sculpture of 20 radial costae, about as wide as interspaces, the anterior seven and posterior eight narrower than median five and with weakly angulate divergent crests. Costae and interspaces bear low, crowded, commarginal lamellae. Ventral margin crenulate. Internal characters not seen.

\section{Dimensions}

$\begin{array}{cccc} & \text { Length } & \text { Height } & \text { Inflation } \\ \text { WAM 06.186 } & 8.9 & 8.5 & 4.7\end{array}$

\section{Remarks}

Unlike any known fossil taxon from southern and south eastern Australia, the specimen is assigned provisionally to Plicacesta with regard to the broader ribs on the median area of each valve. Compared with Plicacesta smithi (G.B. Sowerby, 1888), type species of Plicacesta, from the Recent of Japan, the present species has fewer, more spaced ribs, smaller posterior auricles and lesser size.

\section{Occurrence}

Southern Carnarvon Basin: unnamed sandstone, Middle-Late Eocene.

\section{Family Chamidae}

\section{Genus Chama Linnaeus, 1758}

\section{Chama sp.}

Figures 1.2, 1.3

Material examined

Australia: Western Australia: Kalbarri National Park, ca. $19.5 \mathrm{~km}$ ESE. of Kalbarri: 1 right valve (WAM 06.187).

\section{Description}

A small, probably immature and transposed tumid RV, umbo strongly prosocline, beak incurved. Sculpture of about 14 thin, irregular, spaced commarginal lamellae with faint traces of radial sculpture forming a frill on the edge of the lamellae. Hinge corroded, with traces of poorly preserved cardinals and possible laterals. No lunule or escutcheon apparent. Groove present on umbo, extending onto disc - a possible attachment area. Exterior partly corroded, interior obscured by matrix.

\section{Dimensions}

$\begin{array}{lccc} & \text { Length } & \text { Height } & \text { Inflation } 06.187 \\ \text { WAM } & 7.9 & 8.2 & 5.5\end{array}$

\section{Remarks}

Chama shells are markedly inequivalve and usually attach to firm substrates by cementation of part of the cup-shaped LV. In this "normal" form, the RV is more-or-less flattened and discoidal. Sculpture of the valves is irregularly discrepant, with commarginal elements predominant.

Recent studies (e.g., Matsukuma 1996, Matsukuma et al. 1997) have reported instances of both "normal" and transposed or "inverse" forms of shell within a single species of the genus. In the latter case, valve transposition affecting shell and/or hinge occurs with attachment by the RV. Though poorly preserved, the present specimen from Kalbarri retains probable remnants of a juvenile, pre-settlement form of dentition, such as that noted by Matsukuma (1996: 24). However, in a discussion on the synonymy of the genus Chama and the significance of valve transposition, Beu (2006: 215221) concluded that valve cementation was of little, if any taxonomic significance.

Chama lamellifera Tenison. Woods, 1877 represents the genus from the Late Eocene to Middle Miocene of south-eastern Australia (Harris 1897, Darragh 1985). Examination of all specimens of that species in the collections of Museum Victoria and Western Australian Museum has found no example of valve transposition. Clarification of the relationship of that species to the Kalbarri specimen is deferred until further, better preserved material eventuates. 
A species of Chama, clearly distinct from $C$. lamellifera, is represented in collections (Table 2) from the Middle-Late Eocene Merlinleigh Sandstone of the eastern Central Carnarvon Basin. These large, robust shells, unlike the single Kalbarri Chama, all have "normal" hinge and valveattachment orientation. The relationship of the two populations remains to be clarified, subject to the collection of further material from Kalbarri.

\section{Occurrence}

Southern Carnarvon Basin: unnamed sandstone, Middle-Late Eocene.

\section{Family Lucinidae}

\section{Genus Epicodakia Iredale, 1930}

\section{Epicodakia sp.}

Figure 1.20

\section{Material examined \\ Australia: Western Australia: Kalbarri National Park, ca. 19.5 km ESE. of Kalbarri: fragmentary right valve (WAM 04.207); conjoined valves (WAM 05.182); conjoined valves (NMV P313982). Total of two pairs of valves and one fragmentary right valve.}

\section{Description}

The bivalve is transversely sub-elliptical, extended anteriorly, a little inflated, umbones orthogyrate, beaks proximate and located posterior of centre. Antero-dorsal area excavate, ligament externally visible. Sculpture of radial and commarginal elements, absent from the beaks. Fine, close radials cover the disc, stronger and slightly antimarginal on flanks, fading dorsally. Very fine, close commarginals extend across the disc. Fragmentary RV 04.207 retains hinge, comprising a small, thin, anterior cardinal (3a), a strong, grooved posterior cardinal ( $3 \mathrm{~b})$ and prominent, single laterals (AIII and PIII), both remote from cardinals.

\section{Dimensions}

$\begin{array}{cccc} & \text { Length } & \text { Height } & \text { Inflation } \\ \text { WAM 05.182 } & 10.4 & 8.7 & 5.0\end{array}$

\section{Remarks}

The Kalbarri specimens are not unlike the Recent type species of the genus, Epicodakia tatei (Angas, 1879), differing in its slightly greater anterior extension and finer, more dense sculpture, both radial and commarginal. Comparison with a congenor from the Pallinup Formation at North Walpole (Darragh and Kendrick 1980) shows the Kalbarri specimen to have greater anterior extension and more crowded, persistent sculpture.

\section{Occurrence}

Southern Carnarvon Basin: unnamed sandstone, Middle-Late Eocene.

\section{Family Carditidae}

\section{Génus Glyptoactis Stewart, 1930}

Subgenus Fasciculicardia Maxwell, 1969

Glyptoactis (Fasciculicardia) sp. cf. G.(F.)

latissima (Tate, 1886)

Figure 1.5

Cardita latissima Tate, 1886: 153, plate 2, figure 5.

Cardium arcaeformis Chapman and Crespin, 1934: 121, plate 11 , figures $25-27$.

Venericardia (Fasciculicardia) latissima (Tate): Maxwell 1969: 173-4.

Glans latissima (Tate): Ludbrook 1973: 247, plate 24, figures $11,12$.

Glans (Fasciculicardia) latissima (Tate): Darragh and Kendrick 1980: 17, figures 4G-L.

\section{Material examined}

Australia: Western Australia: Kalbarri National Park, ca. 19.5 km ESE. of Kalbarri: 1 fragmentary left valve (WAM 06.188).

\section{Description}

About 24 radial costellae, about as wide as or narrower than the interspaces, are visible on this incomplete LV. Ribs bear transverse scales on crests, more prominent on anterior and posterior areas.

\section{Dimensions}

The size of the specimen cannot be measured but the estimated length is $6.5 \mathrm{~mm}$.

\section{Remarks}

As far as can be seen, the sculpture of this specimen compares well with others of Tate's species from Brown's Creek, Aldinga and North Walpole.

Ranking Fasciculicardia as a subgenus of Glyptoactis follows the conclusions of Maxwell (in Beu and Maxwell 1990: 102) and Beu (2006: 224), recognising a close relationship between the two.

\section{Occurrence}

Otway Basin: Lower and Upper Browns Creek Formation, Late Eocene. St Vincent Basin: Blanche Point Formation, Late Eocene (type). Bremer Basin: Pallinup Formation, Late Eocene. Southern Carnarvon Basin: unnamed sandstone, Middle-Late Eocene. 


\section{Family Cardiidae}

Genus Pratulum Iredale, 1924

\section{Pratulum hemimeris (Tate, 1887)}

Figure 1.15

Cardium hemimeris Tate, 1887: 153, plate14, figures $2 a-c$.

\section{Material examined}

Australia: Western Australia: Kalbarri National Park, ca. 19.5 km ESE. of Kalbarri: 1 conjoined pair (WAM 04.208).

\section{Description}

Small, conjoined valves, inflated, about as high as long, with prominent, raised median umbones and incurved beaks. Sculpture of very fine, close, simple, radial costellae extending over about the anterior $60 \%$ of shell. Posteriorly, costellae and interspaces widen, with weak transverse scales extending anteriorly from each radial across the adjacent (anterior) interspace. Sculpture appears to be worn, with or without some imperfection in the silica replication of the original aragonitic shell.

\section{Dimensions \\ $\begin{array}{cccc} & \text { Length } & \text { Height } & \text { Inflation } \\ \text { WAM 04.208 } & 124 & 127 & 9.9\end{array}$}

\section{Remarks}

The single specimen to hand from Kalbarri, of this uncommon species, compares well in size and morphology with others from the Blanche Point Formation at Aldinga, South Australia. Three small silicified shell fragments (WAM 83.2605) from the Pallinup Formation at North Walpole, bear cardiidtype sculpture not unlike that of the present species, suggesting a possible presence at that muchcollected locality.

\section{Occurrence}

Otway Basin: Browns Creek Formation, Late Eocene. St Vincent Basin: Blanche Point Formation, Late Eocene (type). Bremer Basin: Pallinup Formation,?, Late Eocene, Southern Carnarvon Basin: unnamed sandstone, Middle-Late Eocene.

\section{Family Veneridae}

\section{Genus Dosina Gray, 1835}

Subgenus Dosina s.str.

\section{Dosina (Dosina) multilamellata (Tate, 1887)}

Figure 1.16

Chione multilamellata Tate, 1887: 154, 155, plate 15, figures $6 \mathrm{a}, \mathrm{b}$.
Dosina (Dosina) multitaeniata (Tate): Ludbrook, 1973: plate 24, figures 18, 19 (invalid replacement name for multilamellata).

Dosina (Dosina) multilamellata (Tate): Darragh and Kendrick 1980: 19.

Material examined

Australia: Western Australia: Kalbarri National Park, ca. 19.5 km ESE. of Kalbarri: conjoined valves (WAM 04.209); 1 fragment (NMV P313983).

\section{Description}

Small, transversely ovate, inflated, with low umbones and prosogyrate beaks. Lunule shallow, broad, bordered by incised line, escutcheon elongate, weakly defined. Sculpture of thin, spaced, commarginal costellae, ca 17 in height of $5.3 \mathrm{~mm}$, beaks smooth.

\section{Dimensions}

$\begin{array}{cccc} & \text { Length } & \text { Height } & \text { Inflation } \\ \text { WAM 04.209 (pair) } & 6.2 & 5.3 & 3.8\end{array}$

\section{Remarks}

The confused taxonomy of Tate's species has been discussed by Darragh and Kendrick (1980). The present single, well-preserved specimen from Kalbarri closely resembles others of similar size from the Blanche Point Formation at Aldinga.

\section{Occurrence}

Bass Basin: Freestone Cove Sandstone, Early Miocene. Port Phillip Basin: Jan Juc Formation, Late Oligocene-Early Miocene. Otway Basin: Upper Browns Creek Formation, Late Eocene. St Vincent Basin: Blanche Point Formation, Late Eocene (type). Bremer Basin: Pallinup Formation, Late Eocene. Southern Carnarvon Basin: unnamed sandstone, Middle-Late Eocene.

\section{Genus Fossacallista Marwick, 1938}

\section{cf. Fossacallista tatei (Cossmann, 1920) Figure 1.7}

Cytherea tenuis Tate, 1886: 159, plate 14, figure 16 (junior homonym). non Hall and Meek, 1854.

Cytherea tatei Cossmann, 1920: 37. nom. nov. for $C$. tenuis Tate, non Hall and Meek, 1854.

Notocallista (Fossacallista) tatei (Cossman): Marwick 1938: 77, plate 14, figures 1-3; Ludbrook, 1973: plate 24, figure 13.

Material examined

Australia: Western Australia: Kalbarri National Park, ca. 19.5 km ESE. of Kalbarri: conjoined valves (WAM 06.189). 


\section{Description}

Conjoined valves, of which RV is deformed by compaction and somewhat corroded, LV corroded anteriorly and dorsally, otherwise intact. Length exceeds height, anteriorly short, posteriorly extended, umbo (LV) low, beaks prosogyrate. Sculpture of fine, close-set, incised commarginal lines, lunule excavate, small.

\section{Dimensions}

$\begin{array}{lccc} & \text { Length } & \text { Height } & \text { Inflation } \\ \text { WAM 06.189 } & 11.3 & 9.1 & 4.3 \\ \text { (deformed pair) } & & & \end{array}$

\section{Remarks}

The present specimen is very close to others from the Blanche Point Formation in the Kent Town (Adelaide) bore, South Australia, the type locality.

\section{Occurrence}

Otway Basin: Browns Creek Formation, Late Eocene, Glen Aire Clay, Early Oligocene. Jan-Juc Formation, Late Oligocene-Early Miocene. St Vincent Basin: Blanche Point Formation, Late Eocene (type). Southern Carnarvon Basin: unnamed sandstone, Middle-Late Eocene.

\section{Family Corbulidae}

\section{Genus Caryocorbula Gardner, 1926}

\section{Caryocorbula pixidata (Tate, 1887)}

Figures 1.9, 1.13, 1.17

Corbula pixidata Tate, 1887: 177, plate 17, figures $12 \mathrm{a}, \mathrm{b}$.

Corbula (Caryocorbula) pixidata (Tate): Darragh and Kendrick 1980: 19, figures 5D-H.

\section{Material examined}

Australia: Western Australia: Kalbarri National Park, ca. 19.5 km ESE. of Kalbarri: conjoined pair (WAM 05.183); 1 left valve (WAM 06.190); conjoined pair (NMV P313984).

\section{Description}

Small, longer than high, inequivalve, LV the more inflated, umbones and beaks prosogyrate, beaks at anterior third, anteriorly rounded, short, posteriorly extended, truncate, posterior area offset by welldefined angulation. Chondrophore (LV) large.

\section{Dimensions}

$\begin{array}{lccc} & \text { Length } & \text { Height } & \text { Inflation } \\ \text { WAM 05.183 (pair) } & 9.4 & 6.4 & 4.4 \\ \text { WAM 06.190 (LV) } & 8.4 & 6.0 & 2.4\end{array}$

\section{Remarks}

Kalbarri specimens compare closely with topotypes of Tate's species from the Blanche Point Formation at Aldinga, South Australia.

\section{Occurrence}

Otway Basin: Lower and upper Browns Creek Formation, Late Eocene. Lower Glen Aire Clay, Early Oligocene. St Vincent Basin: Blanche Point Formation (type), Late Eocene. Bremer Basin: Pallinup Formation, Late Eocene. Southern Carnarvon Basin: unnamed sandstone, Middle-Late Eocene.

\section{Class Scaphopoda}

Family Dentaliidae

Genus Dentalium Linnaeus, 1758

Subgenus Fissidentalium Fischer, 1885

\section{Dentalium (Fissidentalium) mawsoni Ludbrook, 1956}

Figures 2.1, 2.2

Dentalium (Fissidentalium) mawsoni Ludbrook, 1956: 2, 3, plate 1, figures 5, 6 .

Material examined

Australia: Western Australia: Kalbarri National Park, ca. 19.5 km ESE. of Kalbarri: 3 specimens (WAM 04.227); 2 specimens (WAM 05.201); 15 specimens (WAM 06.178); 13 specimens (NMV P313978); 3 specimens (WAM P313979). Total of 36 specimens.

\section{Description}

Medium sized, robust, circular to slightly oval in cross-section, almost straight, curvature slight, where visible, tending toward apex. Ribs fine to very fine, of irregular size and spacing, numbering ca 30 (apex) to ca 50 (aperture), increasing by intercalation. No specimen in the study material is intact, none retaining either apical slit or aperture.

\section{Dimensions \\ WAM 05.201a

$\begin{array}{cc}\text { Length } & \text { Max. diameter } \\ 27 & 5.0 \\ 18 & 3.5\end{array}$

\section{Remarks}

This is one of the more common, widely distributed and long-ranging dentaliid species from the Tertiary of southern Australia, here extended into the later Eocene of the southern Carnarvon Basin. Kalbarri specimens have been compared with topotypes from the Middle Miocene Cadell Marl (Murray Basin) and with Late Eocene material from the Browns Creek Formation (Otway Basin) and are closely comparable. 


\section{Occurrence}

Otway Basin: Browns Creek Formation, Late Eocene. Glen Aire Clay, Oligocene. Jan Juc Formation, Oligo-Miocene. Puebla Formation, Early Miocene. Muddy Creek Formation, Middle Miocene. Fyansford Formation, Early-Middle Miocene. Bass Basin: Freestone Cove Sandstone, Early Miocene. Murray Basin: Cadell Marl Member, Morgan Limestone, Middle Miocene (type). St Vincent Basin: Blanche Point Formation, Late Eocene. Dry Creek Sands, Late Miocene. Bremer Basin: Pallinup Formation, Late Eocene. Southern Carnarvon Basin: unnamed sandstone, Middle-Late Eocene.

\section{Class Gastropoda}

\section{Family Fissurellidae}

\section{Genus Emarginula Lamarck, 1801}

Emarginula sp.

Figures 2.1, 2.2, 2.6

\section{Material examined}

Australia: Western Australia: Kalbarri National Park, ca. $19.5 \mathrm{~km}$ ESE. of Kalbarri: 1 specimen (WAM 04.210).

\section{Description}

Small, probably immature, longer than wide, width and height about equal, margin mostly abraded, in particular on right posterior flank. Apex acute, strongly incurved, close to posterior extremity. Selenizone infilled by raised, tuberculate, median rib, slit absent due to abrasion. Radial ribs ten or eleven, alternating in width and prominence, some very fine, the larger generating tubercles at intersections with fine, near-lamellate concentric ribs. Interior obscured.

\section{Dimensions}

WAM 04.210

$\begin{array}{ccc}\text { Length } & \text { Width } & \text { Height } \\ 5.0 & 2.8 & 2.7\end{array}$

\section{Remarks}

The genus appears to be widespread but sparsely represented in the later Eocene of southern Australia. A species of Emarginula, very similar to that from Kalbarri, is known from a single specimen (NMV P302258) from the Browns Creek Formation. Fragments attributed to Emarginula from the Plantagenet Group of the Bremer Basin (Darragh and Kendrick 2000: 30, 31, figures 4, K, M) appear to be specifically distinct from the present species. The margins of the Kalbarri specimen appear to have sustained crab damage.

\section{Occurrence}

Southern Carnarvon Basin: unnamed sandstone, Middle-Late Eocene.

\section{Family Trochidae}

Genus Micrelenchus Finlay, 1926

Subgenus Plumbelenchus Finlay, 1926

\section{Micrelenchus (Plumbelenchus) armulatus Darragh and Kendrick, 2000}

Figure 2.3

Micrelenchus (Plumbelenchus) armulatus Darragh and Kendrick 2000: 46, figures 6J, $\mathrm{K}$

\section{Material examined}

Australia: Western Australia: Kalbarri National Park, ca. $19.5 \mathrm{~km}$ ESE. of Kalbarri: 1 specimen (WAM 04.212).

\section{Description}

Small, turbiniform, height and diameter about equal, whorls shouldered with distinct subsutural shelf, sculpture of light spiral striae.

\section{Dimensions \\ $\begin{array}{cccc} & \text { Height } & \text { Max. diameter } & \text { No. whorls } \\ \text { WAM 04.212 } & 4.2 & 4.5 & \text { ca } 4.5\end{array}$}

\section{Remarks}

Minor variation in the whorl profile and in the strength and persistence of the sculpture was noted in the type material (Darragh and Kendrick 2000) and the Kalbarri specimen generally compares well with topotypes. In the latter, shell height consistently exceeds maximum diameter, possibly due to the greater size of the North Walpole specimens. Crab damage is evident on the aperture of the present specimen.

\section{Occurrence}

St Vincent Basin: Blanche Point Formation. Bremer Basin: Pallinup Formation (type). Southern Carnarvon Basin: unnamed sandstone, Middle-Late Eocene.

\section{Genus Calliostoma Swainson, 1840}

Subgenus Fautor Iredale, 1924

\section{Calliostoma (Fautor) sp. aff. numapum Darragh and Kendrick, 2000 \\ Figure 2.14}

Calliostoma (Fautor) numapum Darragh and Kendrick, 2000: 48, figure $7 \mathrm{~A}$

\section{Material examined}

Australia: Western Australia: Kalbarri National Park, ca. $19.5 \mathrm{~km}$ ESE. of Kalbarri: 1 specimen (WAM 04.211). 

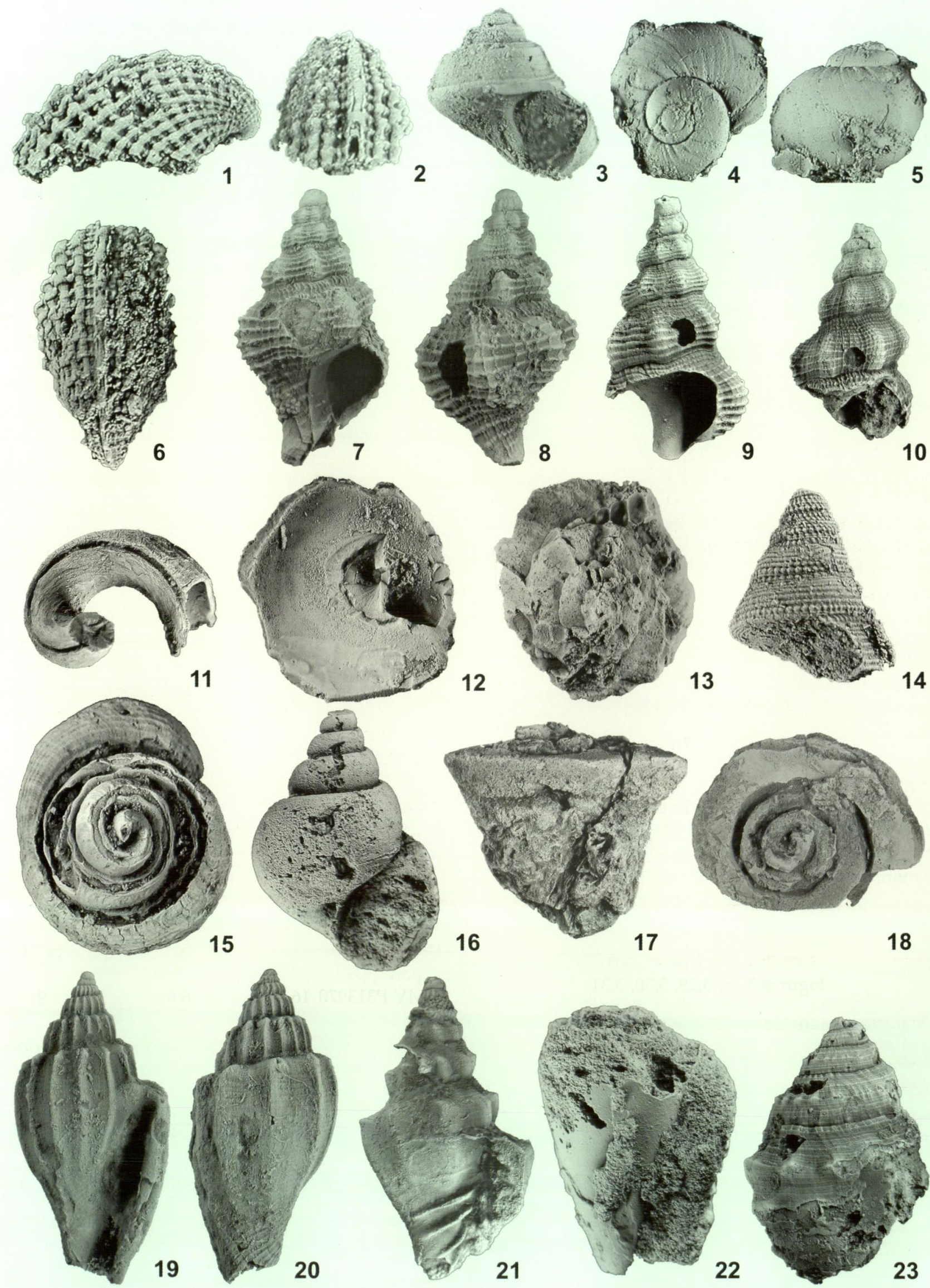


\section{Description}

Small, juvenile, trochiform, higher than wide, spire angle $46^{\circ}$, lacking apical extremity, part of aperture and columella; whorls six, the last incomplete, initially slightly convex, becoming flattened with growth; sutures slightly channelled; sculpture of six narrow spiral threads per whorl, the basal two (i.e. above suture) rather more granose than others; two apical whorls show more radially aligned granulation than subsequently; basal sculpture of fine, close spiral threads.

\section{Dimensions}

$\begin{array}{lccc} & \text { Height } & \text { Max. diameter } & \text { No. whorls } \\ \text { WAM 04.211 } & 4.5 & 3.3 & \text { ca } 6\end{array}$

\section{Remarks}

The single juvenile specimen to hand, lacking the full range of adult characters, nevertheless recalls Calliostoma (Fautor) numapum Darragh and Kendrick from the Pallinup Formation (Darragh and Kendrick 2000), to which it is clearly related. In comparison, the present species has a more acute spire and, as far as can be observed, a more granulate micro-sculpture.

\section{Occurrence}

Southern Carnarvon Basin: unnamed sandstone, Middle-Late Eocene.

\section{Family Cerithiidae}

\section{Genus Cerithium Bruguière, 1789}

\section{Type species}

Cerithium adansonii Bruguière, 1792, by subsequent designation of Melville (1978, ICZN Opinion 1109) = Cerithium erythraeonense Lamarck, 1822 = Cerithium nodulosum. Bruguière, 1792 (= senior synonym, Houbrick, 1992).

Cerithium wilya sp. nov.

Figures $3.28,3.29,3.30,3.31$

\section{Material examined}

Holotype

Australia: Western Australia: Kalbarri National
Park, $19.5 \mathrm{~km}$ ESE. of Kalbarri; ca. $1 \mathrm{~km}$ W of Junga Dam, surface float downslope and west of low ridge, map reference Kalbarri (1:100,000 series) 397260, 14-17 October 2005, T.A. Darragh and G.W. Kendrick (WAM 07.1).

Paratypes

Australia: Western Australia: 2 specimens, collected with holotype (WAM 04.218a, 07.2); 1 specimen, collected with holotype (NMV P313970).

\section{Other material examined}

Australia: Western Australia: all collected with holotype: 14 specimens (WAM 04.218); 5 specimens (WAM 05.189); 34 specimens (WAM 07.3); 36 specimens (NMV P313971). Total of 89 specimens.

\section{Description}

Small for genus, possibly immature; spire narrowly acuminate, subtending angle of $22^{\circ}-25^{\circ}$; whorls of moderate convexity with well-defined sutures; whorls bear persistent varices, ten visible in about eight whorls. Sculpture of narrow, intervariceal radials, numbering seven to twelve between varices and overlain by up to 13 (on last whorl) narrow spirals of uneven spacing and prominence, of which the adapical seven are nodose at the rib intersections; spirals continuous over varices. Aperture invariably broken (crab predation), lacking anal canal; columella rounded, the margin (where retained) forming callus bordering parietal area; remnants of anterior siphonal canal occasionally retained (paratype 04.218a).

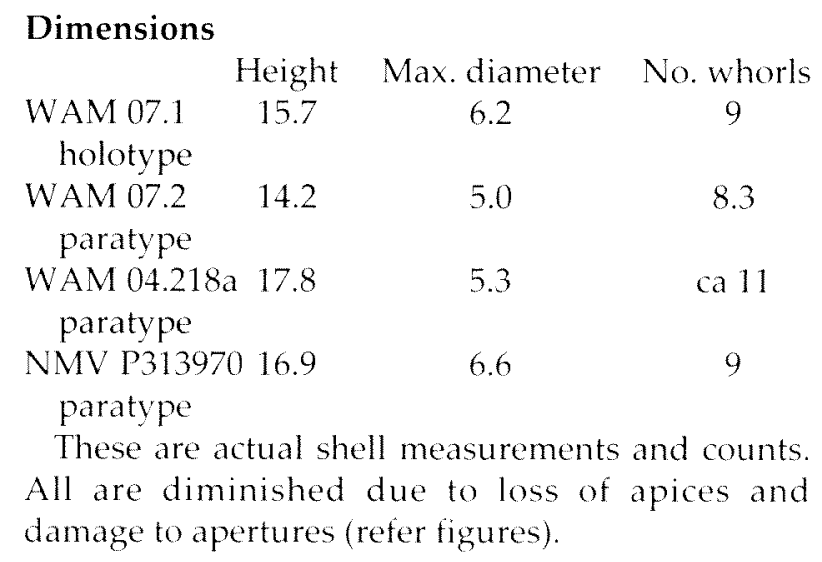

Figure 2 Emarginula sp., 1, 2, 6 WAM 04.210 all x 9.0. Micrelenchus (Plumbelenchus) armulatus Darragh and Kendrick, 3 WAM 04.212 x 7.7. Naticid sp., 4, 5 WAM 04.219 x 7.0. Murexsul sp, 7, 8 WAM 07.13 x 3.8 . Dennantia aldingensis (Tate), 9 WAM 04.223 x 3.0; 10 WAM 05.192 × 2.8. Tenagodus sp., 11 WAM 05.191a $\times$ 2.4; 15 WAM 07.9 x 4.3. Xenophora sp. of. X. tatei Harris, 12, 13 WAM 05.200a x 2.5. Calliostoma (Fautor) sp. aff. C.(F.) numapum Darragh and Kendrick, 14 WAM 004.211 x 8.0. Euspirocrommium sp., 16 WAM 05.185 $x$ 3.0. Turbinellid? sp., 17, 18 WAM 07.133 x 1.0. Lvria lamellatoplicata sp. nov, 19, 20 WAM 07.18 x 2.8, holotype. Alcithoe (Waihaoia) pagodoides (Tate), 21 WAM 07.16 x 2.0. Conus? sp., 22 WAM 05.199 $\times 3.0$. Galeodea sp., 23 WAM $07.11 \times 1.8$. 


\section{Remarks}

In form and sculpture, though not size, the present species somewhat recalls Cerithium torresi E.A. Smith, 1884, an extant species, without known fossil record, from the Indo-SW Pacific (Houbrick 1992: 185-189, figures 135-137). Species somewhat resembling this taxon, are recorded under the generic name Ptychocerithium Sacco,1895, in the Tertiary of Europe (Cossmann 1906). We follow Houbrick (1992), who synonymised Ptychocerithium with Cerithium. C. wilya sp. nov. is one of the more common and characteristic species of the Kalbarri assemblage, inferior in numerical abundance only to a species of Zeacolpus (see below). Most specimens of both species are fragmentary and the apertures on most specimens have been peeled away, possibly by crabs. This appears to be the first record of this tropicalsubtropical genus from the Eocene of Australia.

\section{Etymology}

The specific name is from the indigenous Nhanda vocabulary of the Lower Murchison district: wilya, a shell (Blevins 2001).

\section{Occurrence}

Southern Carnarvon Basin: unnamed sandstone, Middle-Late Eocene.

\section{Family Turritellidae}

\section{Genus Zeacolpus Finlay, 1926}

\section{Zeacolpus bartoni sp. nov.}

Figures 3.8, 3.9, 3.10, 3.32

\section{Material examined}

\section{Holotype}

Australia: Western Australia: Kalbarri National Park, 19.5 km ESE. of Kalbarri; ca. $1 \mathrm{~km}$ W of Junga Dam, surface float downslope and west of low ridge, map reference Kalbarri (1:100,000 series) 397260, 14-17 October 2005, T.A. Darragh and G.W. Kendrick (WAM 07.4).

\section{Paratypes}

Australia: Western Australia: 2 specimens, collected with holotype (WAM 07.5); 1 specimen (NMV P313972).

\section{Other material examined}

Australia: Western Australia: all collected with holotype: 30 specimens (WAM 04.213); 1 specimen (WAM 04.214); 198 specimens (WAM 04.215); 17 specimens (WAM 05.186); 173 specimens (WAM 07.6); 158 specimens (NMV P313973). Total of 577 specimens.

\section{Description}

Shell of average size for genus; whorls slightly rounded, tending to flatten anteriorly on larger specimens. Sutures linear, slightly impressed, in particular on early whorls, becoming shallowly recessed with growth; spire angle of $20^{\circ}$. Sculpture of 9-13 fine spiral lirae, becoming stronger anteriorly, about as wide as interspaces, some weakly granose where crossed by sinuate, colabral growth striae and increasing by intercalation; second spiral adapical to suture usually the most prominent. Larger specimens develop up to 18 spiral lirae per whorl.

\section{Dimensions}

$\begin{array}{cccc} & \text { Height } & \text { Max. diameter } & \text { No. whorls } \\ \begin{array}{c}\text { WAM 07.4 } \\ \text { holotype }\end{array} & 20.8 & 7.1 & 7 \\ \begin{array}{c}\text { WAM 07.5a } \\ \text { paratype }\end{array} & 15.8 & 5.5 & 10 \\ \begin{array}{c}\text { NMV P313972 } \\ \text { paratype }\end{array} & 24.6 & 6.9 & 9 \\ \text { Non } & & & \end{array}$

None of the above retains either apex or intact aperture.

\section{Remarks}

Zeacolpus bartoni is by far the most common mollusc species recovered from the Kalbarri Eocene but, despite this, no intact, undamaged specimen is known. Apices have been retained on several specimens but no aperture has survived, probably as a consequence of crab predation. Abrasion is a feature of early whorls where present.

Spiracolpus aldingae (Tate, 1882), the only other large turritellid known from the Australian Eocene (Darragh 1985), has fewer lirae than the present species, including a prominent, beaded lira at midwhorl. The genus Zeacolpus is well represented (Eocene-Recent) in New Zealand (Marwick 1971). Of the congenor species from there, $Z$. bartoni most resembles the Late Eocene $Z$. lornensis (Marwick) but has more and finer lirae.

Eleven specimens (WAM 04.217, 05.188, 07.8, NMV P314040) in the study material are, for the present, distinguished from Zeacolpus bartoni because of their flattened whorls and reduced spire angle $\left(14^{\circ}\right)$ (Figure 3.10). Though rather worn, the sculpture is similar to that of $Z$. bartoni, of which they may prove to be an extreme variant.

\section{Etymology}

This species is named for Mr David Barton of Kalbarri in recognition of his discovery of the fossils and his generosity in presenting his collection to the Western Australian Museum.

\section{Occurrence}

Southern Carnarvon Basin: unnamed sandstone, Middle-Late Eocene. 
Family Siliquariidae

\section{Genus Tenagodus Guettard, 1770}

Tenagodus sp.

Figures 2.11, 2.15

\section{Material examined}

Australia: Western Australia: Kalbarri National Park, ca. $19.5 \mathrm{~km}$ ESE. of Kalbarri: 3 specimens (WAM 04.220); 5 specimen (WAM 05.191); 1 specimen (WAM 07.9); 9 specimens (WAM 07.10); 9 specimens (NMV P313974). Total of 27 specimens.

\section{Description}

Shell tubular, loosely dextrally coiled, early whorls somewhat planispiral, becoming irregularly twisted; sculptured with irregular, close-set, longitudinal, weakly beaded ribs, crossed in places by very fine commarginal growth striae. Longitudinal slit present with series of holes along length, often infilled with secondary silica.

\section{Dimensions}

WAM 05.191a.

Maximum diameter is $3.5-4.4 \mathrm{~mm}$.

WAM 07.9.

Maximum diameter is $10.4 \mathrm{~mm}$. Height $11 \mathrm{~mm}$. Whorls 3.5 .

\section{Remarks}

All specimens in the study material are fragmentary and some remain enclosed within sponges, as all probably were in life. Very similar, if not identical, specimens of Tenagodus, often preserved within sponges, are common in the Pallinup Formation of North Walpole (Darragh and Kendrick 1980, 2000) and await detailed study. This material from Western Australia is very similar to specimens of Tenagodus from the Early Miocene Freestone Cove Sandstone at Wynyard, Tasmania. $T$. occlusus (Tenison Woods, 1877) from the latter locality was stated not to have a punctured slit and it is unclear as to whether this was because of the poor preservation of the type specimen or because of a valid difference from specimens commonly occurring there, which do have a series of holes along the slit. Because the status of Tenagodus occlusus remains in need of clarification, we prefer to utilise open nomenclature for the present species.

\section{Occurrence}

Southern Carnarvon Basin: unnamed sandstone, Middle-Late Eocene. Bremer Basin?: Pallinup Formation, Late Eocene.

\section{Family Xenophoridae}

\section{Xenophora sp. cf. tatei Harris, 1897}

Figures $2.12,2.13$

Xenophora (Tugurium) tatei Harris, 1897, p. 254, plate 7 , figures $7 a, b$.

\section{Material examined}

Australia: Western Australia: Kalbarri National Park, ca. $19.5 \mathrm{~km}$ ESE. of Kalbarri: 2 specimens (WAM 05.200).

\section{Description}

Shell small, possibly juvenile, trochiform, wider than high, whorls convex, few, enlarging rapidly, stepped and scalloped where not overlain by attached and other detritus; spire angle ca $90^{\circ}$; periphery extended, abraded; base concave, shallowly perforate, umbilical depression finely radially striate within incised circumbilical groove.

\section{Dimensions \\ $\begin{array}{cccc} & \text { Height } & \text { Max. diameter } & \text { No. whorls } \\ \text { WAM 05.200a } & 10.0 & 16.7 & 5+\end{array}$}

\section{Remarks}

Occurrences of species of Xenophora from the Australian Eocene are very rare, none having been recorded from the long-studied assemblages of that age in Victoria and South Australia. However the present species is very similar to a single specimen from the Pallinup Formation at North Walpole, which bears a close resemblance to the common Middle Miocene Xenophora tatei. This material is to be the subject of a future study.

\section{Occurrence}

Southern Carnarvon Basin: unnamed sandstone, Middle-Late Eocene. Bremer Basin?: Pallinup Formation, Late Eocene.

\section{Family Naticidae}

Naticid, genus and species undetermined Figures 2.4, 2.5

\section{Material examined}

Australia: Western Australia: Kalbarri National Park, ca. $19.5 \mathrm{~km}$ ESE. of Kalbarri: 1 specimen (WAM 04.219).

\section{Description}

Shell small, probably juvenile, with aperture and base obscured by matrix. Low spired, globose, wider than high, with convexly rounded whorls, smooth apart from short, colabral, axial costellae below the suture. 


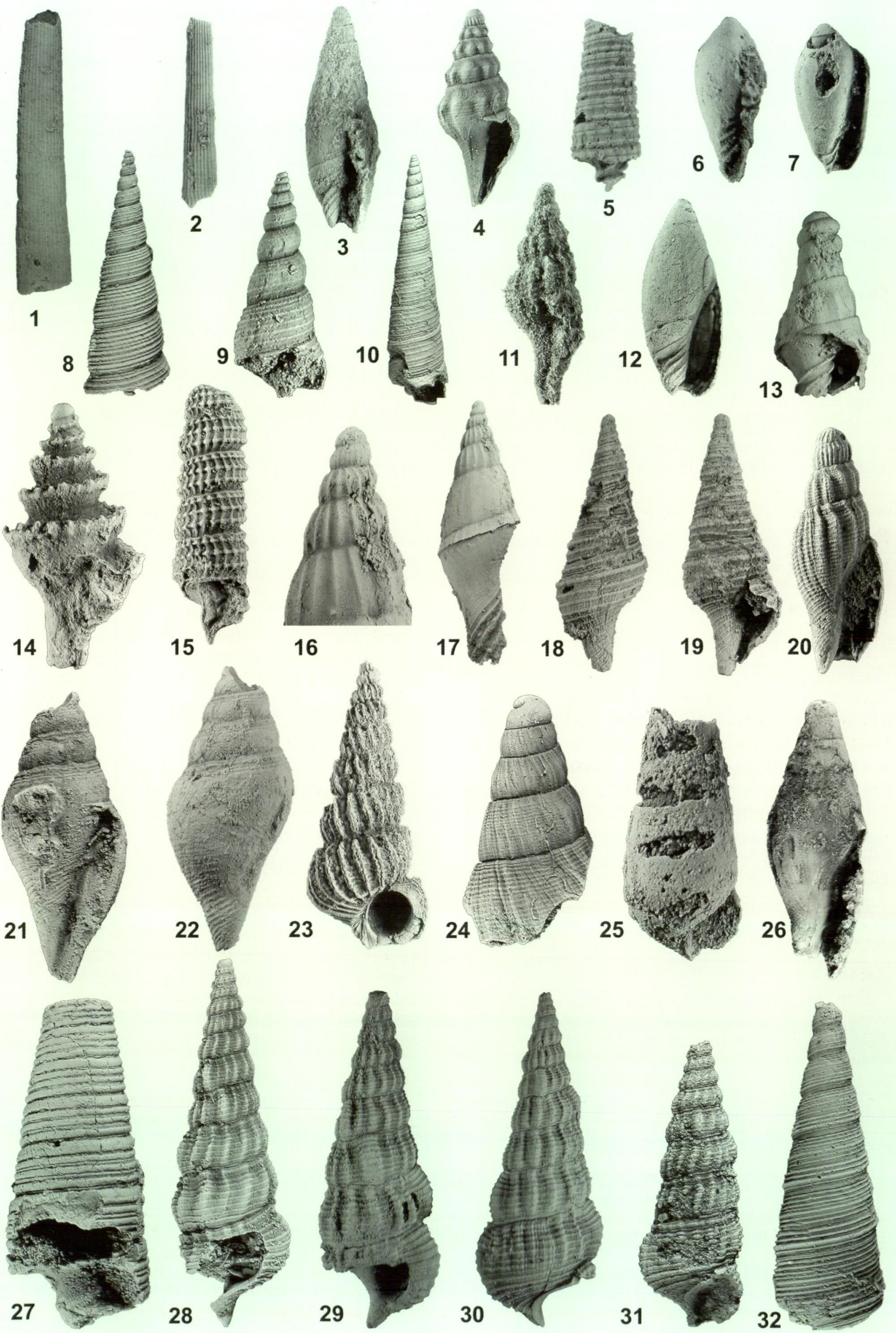




\section{Dimensions}

$\begin{array}{cccc} & \text { Height } & \text { Max. diameter } & \text { No. whorls } \\ \text { WAM 04.219 } & 3.3 & 4.1 & 3.3\end{array}$

\section{Remarks}

What can be seen of this small specimen bears a close resemblance to Friginatica aldingensis (Tate, 1893) from the Late Eocene Blanche Point Formation (Ludbrook 1973, plate 25, figures 57, 58) and also common in the Pallinup Formation of North Walpole (WAM collection).

\section{Occurrence}

Southern Carnarvon Basin: unnamed sandstone, Middle-Late Eocene.

\section{Genus Euspirocrommium Sacco, 1890}

\section{Euspirocrommium sp.}

Figure 2.16

\section{Material examined}

Australia: Western Australia: Kalbarri National Park, ca. $19.5 \mathrm{~km}$ ESE. of Kalbarri: 1 specimen (WAM 05.185).

\section{Description}

Small for genus, with elevated, gradate spire, evenly and convexly rounded whorls and incised, channelled sutures; apex missing, spire angle of $60^{\circ}$. Base narrowly perforate with shallow umbilicus; aperture higher than wide, outer lip broken, as is narrow extension of columella over part of umbilicus. Whorls appear to be smooth but under magnification, seen to bear very fine, crowded colabral and spiral micro-striae, extending to the umbilical area.

\section{Dimensions}

$\begin{array}{cccc} & \text { Height } & \text { Max. diameter } & \text { No. whorls } \\ \text { WAM 05.185 } & 16.3 & 11.5 & 4.6+\end{array}$

\section{Remarks}

This unique specimen from Kalbarri presents a more gradate spire, slightly stronger sculpture and more widely channelled suture when compared with its only known Australian congenorEuspirocrommium effusa (Tate, 1893)-from the Late Eocene Blanche Point and Browns Creek Formations of the St Vincent and Otway Basins respectively. It somewhat resembles $E$. levesquei (d'Orbigny) from the Eocene of the Paris Basin.

\section{Occurrence}

Southern Carnarvon Basin: unnamed sandstone, Middle-Late Eocene.

\section{Family Cassidae}

\section{Genus Galeodea Link, 1807}

\section{Galeodea sp.}

Figure 2.23

\section{Material examined}

Australia: Western Australia: Kalbarri National Park, ca. 19.5 km ESE. of Kalbarri: 1 specimen (poorly preserved) (WAM 07.11).

\section{Description}

Spire moderately elevated with convex, subgradate whorls; sculpture of numerous, mostly narrow, spiral threads of variable width and spacing, with prominent axial plicae at a weak midwhorl shoulder; subordinate sculpture of very fine, close, axial striae between and overlying the spirals. Apex and aperture missing.

\section{Dimensions}

$\begin{array}{lccc} & \text { Height } & \text { Width } & \text { No. whorls } \\ \text { WAM 07.11 } & 25 & 16 & 4+\end{array}$

\section{Remarks}

From what remains, the specimen bears a close resemblance to those of an undescribed species from the Late Eocene Browns Creek Formation and Early Oligocene Glen Aire Clay of the Otway Basin (Museum Victoria collection).

Figure 3 Dentalium (Fissidentalium) mawsoni Ludbrook, 1 WAM 05.201a, fragment $\times 2.0 ; 2$ WAM 05.201b, fragment $\times$ 2.0. Gemmoliva adelaidae (Tate), 3 WAM 07.135 x 4 . Mauidrillia sp. cf. $M$. aldingensis Powell, 4 WAM 07.30 x 5.0. Notoseila sp., 5 WAM 04.216 x 1.8; 27 WAM 05.187 x 4.1. Marginella sp. A, 6 WAM 04.224 x 4.7. Marginella sp. B, 7 WAM 05.195 × 5.0. Zeacolpus bartoni sp. nov., 8 WAM $07.5 \times 3.0$, paratype; 9 WAM $04.215 \times 7.7$, paratype; 32 WAM $07.4 \times 3.0$, holotype, Zeacolpus sp. 10 WAM $07.8 \times 3.0$. Brocchitas? sp., 11 WAM $07.15 \times 5.5$. Gracilispira sp. cf. G. ligata (Tate), 12 WAM $07.22 \times 4.0$. Notovoluta capitonica Darragh, 13 WAM $05.198 \times$ 2.6. Cochlespira sp., 14 WAM $07.23 \times 5.0$. Cerithiella sp., 15 WAM $05.190 \times 4.8$. Notopeplum protorhysum (Tate), WAM $05.193 \times 3.0 ; 16 \times 3.0,17 \times 2.0$. Gemmula? sp., 18, 19 WAM 06.191 x 3.0. Parasyngenochilus sp. cf. $P$. angustior Long, 20 WAM $07.24 \times 5.0$. Conorbis sp., 21,22 WAM 07.29 $\times 3.0$. Cirsotrema sp. aff. C. pleiophylla (Tate), 23 WAM 04.221 x 4.0. Mitrid sp. A, 24 WAM 05.194 x 5.7. Margineulima? sp., 25 WAM 07.134 x 7.0. Mitrid sp. B, 26 WAM 07.28 x 1.5. Cerithium wilya sp. nov., 28 WAM 04.218a x 4.0, paratype; 29, 30 WAM 07.1 × 4.5, holotype; 31 WAM 07.2 x 3.9, paratype. 


\section{Occurrence}

Southern Carnarvon Basin: unnamed sandstone, Middle-Late Eocene.

\section{Family Cerithiopsidae}

Genus Notoseila Finlay, 1926

Notoseila sp.

Figures 3.5, 3.27

\section{Material examined}

Australia: Western Australia: Kalbarri National Park, ca. $19.5 \mathrm{~km}$ ESE. of Kalbarri: 1 specimen (WAM 04.216); 2 specimens (WAM 05.187). Total of three specimens, all fragmentary.

\section{Description}

Spire whorls flat. Sculpture of spiral lirae, number increasing by intercalation with growth; early whorls with four broad lirae, some crenulated; at diameter of three $\mathrm{mm}$, two lirae adjacent to sutures are widest, others (two) narrower, ribbon-like; at diameter six mm, lirae adjacent sutures are widest, others (four) narrower. Aperture with one strong columellar plait, otherwise not retained; apex missing.

\section{Dimensions}

WAM 04.216

$$
\text { Height Max. diameter }
$$

WAM $05.187 \quad 16.2$

All specimens are fragmentary.

\section{Remarks}

Meaningful comparison with other taxa awaits the collection of better preserved specimens from Kalbarri.

\section{Occurrence}

Southern Carnarvon Basin: unnamed sandstone, Middle-Late Eocene.

\section{Genus Cerithiella Verrill, 1882}

\section{Cerithiella sp.}

Figure 3.15

\section{Material examined}

Australia: Western Australia: Kalbarri National Park, ca. $19.5 \mathrm{~km}$ ESE. of Kalbarri: 2 specimens (WAM 04.219); 1 specimen (WAM 05.190); 1 specimen (NMV P313975). Total of four specimens.

\section{Description}

All specimens are fragmentary. Sculpture comprises three prominent, well spaced spiral lirae, crossed by about 27 thin axial costae, which form small tubercles at the intersection with the spirals. Base with one thin spiral below plane of sutural attachment, within which are about eight, faint, close radial costellae. Siphonal canal twisted. Apex and most of aperture missing.

\section{Dimensions}

$\begin{array}{ccc} & \text { Height } & \text { Max.diameter } \\ \text { WAM } 05.190 & 10.2 & 3.2\end{array}$

This, the figured specimen, retains five whorls.

\section{Remarks}

No specimen known from the Pallinup Formation, Bremer Basin, resembles this species, which may be new.

\section{Occurrence}

Southern Carnarvon Basin: unnamed sandstone, Middle-Late Eocene.

\section{Family Epitoniidae}

\section{Genus Cirsotrema Mörch, 1852}

Cirsotrema sp. aff. pleiophylla (Tate, 1890)

Scalaria (Cirsotrema) pleiophylla Tate, 1890: 231; Tate, 1892, plate 12, figure 1 .

Figure 3.23

Material examined

Australia: Western Australia: Kalbarri National Park, ca. 19.5 km ESE. of Kalbarri: 1 specimen (WAM 04.221).

\section{Description}

Shell of normal size for genus with 17 lamellate, frilled, axial costae on last whorl and about nine very fine, intercostal spirals on the spire whorls and about $12+$ on the last whorl. Base with a spiral rib at the plane of sutural attachment; aperture subcircular, slightly higher than wide; columella expanded, merging with a low, weak, spiral rib. Apical whorls missing.

\section{Dimensions}

Height Max. diameter No. whorls

\section{Remarks}

Intercostal sculpture on the single specimen to hand is partly obscured so that counts of the spiral lirae are approximate only. It is similar to specimens of Cirsotrema pleiophylla from the Late Eocene Blanche Point Formation (St Vincent Basin) and Browns Creek Clay (Otway Basin) but seems to have more numerous and finer lirae and slightly fewer costae per whorl. At the time of writing, no 
congenor species is known from the Pallinup Formation (Bremer Basin).

\section{Occurence}

Southern Carnarvon Basin: unnamed sandstone, Middle-Late Eocene.

\section{Family Eulimidae}

Genus Margineulima Cossmann, 1888

\section{Margineulima? sp.}

Figure 3.25

\section{Material examined}

Australia: Western Australia: Kalbarri National Park, ca. 19.5 km ESE. of Kalbarri: 1 specimen (WAM 07.134).

\section{Description}

The specimen retains less than three whorls, which are flat and probably smooth; base imperforate; aperture poorly preserved, columella slightly curved with a small reflexed callus.

\section{Dimensions}

$\begin{array}{lccc} & \text { Height } & \text { Max. diameter } & \text { No. whorls } \\ \text { WAM 07.134 } & 6.9 & 3.0 & <3\end{array}$

\section{Remarks}

This poorly preserved, single specimen does little more than establish the presence of the family in the study material.

Confirmation of its generic identity awaits the collection of better preserved specimens. It differs from the widely distributed (geographical and stratigraphical) Margineulima danae (Tenison Woods, 1879) from southern Australia in its narrower spire angle and imperforate base.

\section{Occurrence}

Southern Carnarvon Basin: unnamed sandstone, Middle-Late Eocene.

\section{Family Turbinellidae}

Turbinellid, genus and species undetermined Figures 2.17, 2.18

\section{Material examined}

Australia: Western Australia: Kalbarri National Park, ca. 19.5 km ESE. of Kalbarri: 1 specimen (WAM 07.133).

\section{Description}

The single specimen to hand is a much weathered, internal mould, retaining a few shell remnants. It indicates a shell of possible turbinellid form with low, flattened spire, angulate shoulder and extended, tapering last whorl; aperture narrow, the columella bearing (from moulds) two strong plaits on anterior half; base possibly narrowly imperforate.

\section{Dimensions}

$\begin{array}{cccc} & \text { Height } & \text { Max. diameter } & \text { No. whorls } \\ \text { WAM 07.133 } & 39.5 & 43.6 & 4.5+\end{array}$

\section{Remarks}

Despite its conoid shape, a location for this unique specimen in the family Conidae seems most unlikely, due to the apparent presence of two columellar plaits. A tudicline or vasinine affinity for the species seems likely, subject to the collection of further specimens. Neither of these subfamilies is presently known from the Australian Eocene.

\section{Occurrence}

Southern Carnarvon Basin: unnamed sandstone, Middle-Late Eocene.

\section{Family Muricidae}

Genus Murexsul Iredale, 1915

Murexsul sp.

Figures 2.7, 2.8

Material examined

Australia: Western Australia: Kalbarri National Park, ca. $19.5 \mathrm{~km}$ ESE. of Kalbarri: One complete specimen and one fragment (WAM 07.13); 1 specimen (NMV P313976). Total of three specimens.

\section{Description}

Small for genus, fusiform, spire equal to half height. Protoconch large, rounded, smooth, of about 1.5 whorls. Spire whorls convex, gradate, bearing broad axial costae, six on last whorl, seven on penultimate whorl; costae overlain with scaled spiral lirae, 12 on last whorl and five on penultimate whorl; scales present where lirae crossed by prominent growth lines. Outer lip broken; canal short, strongly twisted.

\section{Dimensions}

$\begin{array}{lccc} & \text { Height } & \text { Max. diameter } & \text { No. whorls } \\ \text { WAM 07.13a } & 13.3 & 7.6 & 5.5\end{array}$

\section{Remarks}

The species bears some resemblance to Murexsul prionotus (Tate, 1888) from the Late Eocene Blanche Point Formation (St Vincent Basin) but lacks the foliaceus costae of that species. A congenor, somewhat similar but possibly of a distinct species, 
occurs in the Pallinup Formation at North Walpole (WAM collection).

\section{Occurrence}

Southern Carnarvon Basin: unnamed sandstone, Middle-Late Eocene.

Genus Brocchitas Finlay, 1927

\section{Brocchitas? sp. \\ Figure 3.11}

Material examined

Australia: Western Australia: Kalbarri National Park, ca. $19.5 \mathrm{~km}$ ESE. of Kalbarri: 1 specimen (WAM 07.15).

\section{Description}

Shell small, probably less than fully mature, fusiform. Protoconch acute, smooth, of about 1.5 whorls. Teleoconch of three whorls with prominent axial costae, about ten per whorl and 20 spiral lirae on last whorl; canal long, slightly twisted. Aperture broken.

\section{Dimensions}

$\begin{array}{cccc} & \text { Height } & \text { Max. diameter } & \text { No. whorls } \\ \text { WAM 07.15 } & 7.4 & 2.7^{*} & \text { ca } 5 \\ \text { *probably larger on intact aperture } & \end{array}$

\section{Remarks}

The genus Brocchitas has been recorded hitherto only from the Middle Miocene of South Australia and Victoria (Tate, 1888, and Museum Victoria Collection) and the specimen from Kalbarri, which is less than well-preserved is referred to that genus with some reservations. Compared with $B$. exilis (Tate, 1888), type species of Brocchitas, the present species has a smaller, more acute protoconch, more axial costae and more spiral lirae on the last whorl. An ancestral relationship to $B$. exilis seems possible, to be clarified from the collection of further material.

No comparable specimen is known from the Pallinup Formation, Bremer Basin.

\section{Occurrence}

Southern Carnarvon Basin: unnamed sandstone, Middle-Late Eocene.

\section{Family Fasciolariidae}

\section{Genus Dennantia Tate, 1888}

\section{Dennantia aldingensis (Tate, 1888)}

Figures 2.9, 2.10

Peristernia aldingensis Tate, 1888: 156, plate 8, figure $8 \mathrm{a}-\mathrm{b}$.

\section{Material examined}

Australia: Western Australia: Kalbarri National Park, ca. 19.5 km ESE. of Kalbarri: 3 specimens (WAM 04.222); 1 specimen (WAM 04.223); 1 specimen (WAM 05.192); 4 specimens (WAM 07.14); 3 specimens (NMV P313977). Total of 12 specimens.

\section{Description}

Size average for genus, fusiform with strongly convex whorls. Protoconch of two smooth whorls, the first deviated from shell axis. Axial sculpture of prominent, broad costae, six to eight on last whorl, crossed by 18-20 fine, spiral lirae (last whorl). Inner lip finely lirate.

$\begin{array}{cccc}\text { Dimensions } & & & \\ & \text { Height } & \text { Max. diameter } & \text { No. whorls } \\ \text { WAM 04.222 } & 16.0 & 9.4 & 6+ \\ \text { WAM 05.192 } & 14.1 & 13.3 & 5+\end{array}$

\section{Remarks}

All specimens in the study material are broken, either apically or at the aperture or both but taken together they agree in morphology with topotypes of Dennantia aldingensis. The species is not uncommon in the Pallinup Formation at North Walpole and elsewhere (WAM Collection). Specimen WAM 05.192 has what appears to be a circular, naticiform?, borehole on the last whorl (Figure 2.10).

\section{Occurrence}

Late Eocene of Otway Basin, St Vincent Basin (type), Bremer Basin: Pallinup Formation. Southern Carnarvon Basin: unnamed sandstone, Middle-Late Eocene.

\section{Family Volutidae}

Genus Alcithoe H. and A. Adams, 1853

Subgenus Waihaoia Marwick, 1926

Alcithoe (Waihaoia) pagodoides (Tate, 1888) Figure 2.21

Voluta pagodoides Tate, 1888: 176, plate 13, figure 7; Tate, 1889: 132.

Alcithoe (Waihaoia) pagodoides (Tate): Darragh 1989: 239, plate 12, figures $1,4,7,10,13,17$.

\section{Material examined}

Australia: Western Australia: Kalbarri National Park, ca. $19.5 \mathrm{~km}$ ESE. of Kalbarri: 1 specimen (WAM 04.225); 3 specimens (WAM 05.197); 1 specimen (WAM 07.16); 8 specimens (WAM 07.17); 8 specimens (NMV P313986). Total of 21 specimens, mostly fragmentary. 


\section{Description}

Shell of less than mature size, fusiform, with turreted, gradate spire; anterior fifth missing. Protoconch smooth, of two whorls, aligned with shell axis; first teleoconch whorl with ca 12 axial costellae and thin, spiral lirae; axials subsequently form sharp tubercles on angulate shoulders of whorls; tubercles number eight on last whorl; spirals weaken with growth, absent after ca 6.5 whorls. Columella with four strong plaits and one weaker, posterior plait.

\section{Dimensions}

$\begin{array}{cccc} & \text { Height } & \text { Max. diameter } & \text { No. whorls } \\ \text { WAM 07.16 } & 28.0 & 15.5^{*} & 7 \\ \text { * aperture broken } & & \end{array}$

\section{Remarks}

Alcithoe (Waihaoia) pagodoides is extremely variable in morphology, both geographically and stratigraphically (Darragh 1989), the present specimens from Kalbarri being of comparatively squat form, compared with those from the eastern extremity of its range, i.e., Victoria.

\section{Occurrence}

Otway Basin: Browns Creek Formation. St Vincent Basin: Blanche Point Formation (type). Bremer Basin: Pallinup Formation. South Carnarvon Basin: unnamed sandstone, Middle-Late Eocene. Late Eocene - Late Oligocene.

\section{Genus Notovoluta Cotton, 1946}

\section{Notovoluta capitonica Darragh, 1989} Figure 3.13

Notovoluta capitonica Darragh, 1989: 218, plate 3, figures $8,11,12,15$; plate 27 , figures 1,4 .

\section{Material examined}

Australia: Western Australia: Kalbarri National Park, ca. $19.5 \mathrm{~km}$ ESE. of Kalbarri: 1 specimen (WAM 05.198).

\section{Description}

Specimen comprises the adapical part of a probable juvenile or immature shell. Protoconch turbinate, of about three convex whorls, slightly wider than first teleoconch whorl. About 21/2 slender teleoconch whorls, gradually forming low axial costae, on which weak plicae develop at a little above mid-whorl; spire profile almost straight; by fourth whorl, fine, close, spiral lirae extend between sutures, passing over axial costae and plicae. Four columella plaits present. Aperture missing.

\section{Dimensions}

$\begin{array}{lccc} & \text { Height } & \text { Max. diameter } & \text { No. whorls } \\ \text { WAM 05.198 } & 13.0 & 6.5 & 51 / 2\end{array}$

\section{Remarks}

Though comprising only the protoconch and several early whorls of the teleoconch, sufficient characters remain on this specimen to make comparison with topotypes of Notovoluta capitonica, which it matches very closely.

\section{Occurrence}

Otway Basin: Browns Creek Formation (type). St Vincent Basin: Blanche Point Formation. Late Eocene. Southern Carnarvon Basin: unnamed sandstone, Middle-Late Eocene.

\section{Genus Notopeplum Finlay, 1927}

\section{Notopeplum protorhysum (Tate, 1889)}

Figures 3.16, 3.17

Voluta protorhysa Tate, 1889: 126, plate 2, figures $6 \mathrm{a}, \mathrm{b}$.

Notopeplum protorhysum (Tate): Darragh 1989: 256,257 , plate 25 , figures $7,10,11$, figure 31 .

\section{Material examined}

Australia: Western Australia: Kalbarri National Park, ca. $19.5 \mathrm{~km}$ ESE. of Kalbarri: 1 specimen (WAM 05.193).

\section{Description}

Shell small, immature, without last whorl and anterior extremity as if from crab peeling. Protoconch worn; first teleoconch whorl bears numerous, fine, close, axial costellae, persisting and becoming spaced on subsequent three whorls, then fading. Columella with four strong and one thin plaits, with several faint spirals, fading adapically.

\section{Dimensions}

Height Max. diameter No. whorls $\begin{array}{llll}\text { WAM } 05.193 & 25.4 & 8.3 & \text { ca } 6\end{array}$

All dimensions are less than the original

\section{Remarks}

The single specimen is very close in morphology to Tate's figured specimen from the Kent Town Bore, Adelaide.

\section{Occurrence}

Otway Basin: Browns Creek Formation. St Vincent Basin: Blanche Point Formation (type). Bremer Basin: Pallinup Formation. Southern Carnarvon Basin: unnamed sandstone. Middle-Late Eocene. 
Genus Lyria Gray, 1847

Lyria lamellatoplicata sp. nov. Figures 2.19, 2.20

Material examined

\section{Holotype}

Australia: Western Australia: Kalbarri National Park, $19.5 \mathrm{~km}$ ESE. of Kalbarri; ca. $1 \mathrm{~km}$ W of Junga Dam, surface float downslope and west of low ridge, map reference Kalbarri (1:100,000 series) 397260, 14-17 October 2005, T.A. Darragh and G.W. Kendrick (WAM 07.18).

\section{Paratypes}

Australia: Western Australia: 1 specimen, collected with holotype (WAM 07.19); 1 specimen, collected with holotype (NMV P313987).

\section{Other material examined}

Australia: Western Australia: all collected with holotype: 1 specimen (WAM 05.196); 3 specimens (WAM 07.20); 4 specimens (NMV P313988). Total of 11 specimens.

\section{Description}

Shell small for the genus, possibly immature. Protoconch of 1.5 whorls, the first deviated about $45^{\circ}$ from shell axis. Teleoconch of about five gradate whorls with high, narrow whorl shoulder. Axial sculpture of thin, sharp, almost plate-like costae extending from suture to suture, 14 on penultimate whorl, 11 on last whorl, interspaces much wider than costae. Spiral sculpture of numerous, weak threads extending over all teleoconch whorls. Aperture narrow, elongate, outer lip thickened; columella with two to five strong plaits with occasionally one or two weaker plaits present.

\begin{tabular}{|c|c|c|c|}
\hline \multicolumn{4}{|l|}{ Dimensions } \\
\hline & Height & Max. diameter & No. whorls \\
\hline $\begin{array}{c}\text { WAM } 07.18 \\
\text { holotype }\end{array}$ & 19.9 & 9.8 & 6 \\
\hline $\begin{array}{l}\text { WAM } 07.19 \\
\text { paratype }\end{array}$ & 18.8 & 9.4 & $3.5+$ \\
\hline $\begin{array}{l}\text { NMV P313987 } \\
\text { paratype } \\
\text { All specimen }\end{array}$ & 18.2 & 8.2 & 5 \\
\hline
\end{tabular}

\section{Remarks}

The species bears no close resemblance to any other known congenor from Australia. It bears a superficial similarity to Lyria branderi (Deshayes, 1835) from the Eocene of the Paris Basin but differs in that the costae of the last whorl are much more widely spaced and much narrower than on the latter. No species of Lyria is as yet known from the Eocene strata of southeastern Australia but an undescribed congenor is present in the Pallinup Formation of the Bremer Basin (WAM Collection).

\section{Etymology}

The specific name is from the Latin lamellata, and plica, a fold, referring to the lamella-like costae.

\section{Occurrence}

Southern Carnarvon Basin: unnamed sandstone, Middle-Late Eocene.

\section{Family Olividae}

Genus Gemmoliva Iredale, 1924

Gemmoliva sp. cf. G. adelaidae (Tate, 1889) Figure 3.3

Oliva adelaidae Tate, 1889: 145, plate 8, figure 6 .

Material examined

Australia: Western Australia: Kalbarri National Park, ca. $19.5 \mathrm{~km}$ ESE. of Kalbarri: 1 specimen (WAM 07.135).

\section{Description}

Shell small, of average size for species, spire and aperture partly obscured by matrix. Spire whorls flattened, sutures narrowly channelled, spire half total height, spire angle $30^{\circ}$, narrowly elongate; columella with three strong plaits set on callus; last whorl with anteriorly located spiral band bordered by narrow, incised lines, which extend onto parietal area as two narrow, spaced threads. Apex rounded, smooth.

\section{Dimensions}

Height Max. diameter No. whorls $\begin{array}{llll}\text { WAM 07.135 } & 10.9 & 3.6 & 6\end{array}$

\section{Remarks}

The single specimen from Kalbarri is more elongate and has a more narrowly channelled suture than those of Gemmoliva adelaidae from the Browns Creek and Blanche Point Formations.

\section{Occurrence}

Southern Carnarvon Basin: unnamed sandstone, Middle-Late Eocene.

\section{Genus Gracilispira Olson, 1956}

Gracilispira sp. cf. G. ligata (Tate, 1889)

Figure 3.12

Ancillaria ligata Tate, 1889: 147, plate 7, figure 6. 
Material examined

Australia: Western Australia: Kalbarri National Park, ca. $19.5 \mathrm{~km}$ ESE. of Kalbarri: 1 specimen (WAM 07.22).

\section{Description}

Shell small for species, immature. Spire flattened, equal to half total height, sutures weakly apparent; apex bluntly rounded. Columella with four close plaits; broad spiral band at anterior extremity enters aperture adapical to plaits.

\section{Dimensions}

$\begin{array}{cccc} & \text { Height } & \text { Max. diameter } & \text { No. whorls } \\ \text { WAM 07.22 } & 9.5 & 3.7 & 6\end{array}$

\section{Remarks}

The single specimen is close to Tate's species but is more tumid than others of similar size from the Blanche Point (type) and Browns Creek Formations.

\section{Occurrence}

Southern Carnarvon Basin: unnamed sandstone, Middle-Late Eocene.

\section{Family Turridae}

\section{Genus Cochlespira Conrad, 1865}

\section{Cochlespira sp.}

Figure 3.14

\section{Material examined}

Australia: Western Australia: Kalbarri National Park, ca. $19.5 \mathrm{~km}$ ESE. of Kalbarri: 1 specimen (WAM 07.23).

\section{Description}

Shell fusiform with strongly gradate spire, whorls channelled below sutures and with a strong peripheral rim, bearing low, subspinose plicae, numbering ca 20 on last whorl. Aperture concealed by matrix, anterior canal broken, remnant with six close, spiral lirae; several weak spirals on parietal area of last whorl. Protoconch smooth, worn, of $1+$ whorls, first teleoconch whorl with fine, close axial costellae.

\section{Dimensions}

$\begin{array}{cccc} & \text { Height } & \text { Max. diameter } & \text { No. whorls } \\ \text { WAM 07.23 } & 10.3 & 5.5 & \text { ca } 7\end{array}$

\section{Remarks}

The single Kalbarri specimen is slightly larger than those of Cochlespira semiplana (Powell, 1944) from the Browns Creek and Blanche Point (type) Formations. It is also more gradate and lacks the prominent lira present on the last whorl of the latter species.

\section{Occurrence}

Southern Carnarvon Basin: unnamed sandstone, Middle-Late Eocene.

\section{Genus Parasyngenochilus Long, 1981}

Parasyngenochilus sp. cf. P. angustior Long, 1981 Figure 3.20

Parasyngenochilus angustior Long, 1981: 50, plate 7, figure. 17.

\section{Material examined}

Australia: Western Australia: Kalbarri National Park, ca. $19.5 \mathrm{~km}$ ESE. of Kalbarri: 1 specimen (WAM 07.24); 1 specimen (NMV P313989). Total of two specimens.

\section{Description}

Shell elongate-fusiform with blunt apex. Protoconch smooth, paucispiral, of about 1.5 whorls. First teleoconch whorl with fine, close, axial costellae, subsequently becoming more spaced and overlain by fine, close spiral lirae, extending from suture to suture and continuous over axials; one stronger, composite spiral formed anterior of suture and is bordered by a shallow spiral depression; last whorl with 18 low axial costae of unequal strength and spacing, some composite; spiral lirae continuous over last whorl and extending onto anterior canal, tip of which is broken. Columella slightly callused with several faint, ascending spiral lirae.

\section{Dimensions \\ Height Max. diameter No. whorls $\begin{array}{llll}\text { WAM } 07.24 & 9.3 & 3.4 & 5\end{array}$}

\section{Remarks}

The figured specimen is well-preserved apart from a broken anterior canal and infilled aperture; the second specimen to hand, though of inferior preservation, attains a height of $12.5 \mathrm{~mm}$. Of the species of Parasyngenochilus recorded from the Late Eocene-Early Oligocene of the Otway and St Vincent Basins, the present species, most resembles. $P$. angustior, differing in its more ill-defined shoulder and fewer, more regular and more evenly spaced lirae. The genus also occurs in the Late Eocene to Late Oligocene of New Zealand (Long, 1981: 50). No congenor is as yet known from the Pallinup Formation, Bremer Basin.

\section{Occurrence}

Southern Carnarvon Basin: unnamed sandstone, Middle-Late Eocene. 


\section{Genus Gemmula Weinkauff, 1876}

Gemmula? sp.

Figures $3.18,3.19$

\section{Material examined}

Australia: Western Australia: Kalbarri National Park, ca. 19.5 km ESE. of Kalbarri: 1 specimen (WAM 06.191); 1 fragmentary specimen (NMV P314038). Total of two specimens.

\section{Description}

Shell somewhat worn, acuminate-fusiform, spire ca two thirds total height. Protoconch of ca 1.5 whorls, slighly deviated; teleoconch whorls spirally lirate throughout with a weakly gemmulate peripheral keel at about mid-whorl; between keel and adapical suture are one relatively prominent and three or four very fine spiral lirae; anterior of keel are two relatively prominent lirae on spire whorls and three on last whorl, with additional very fine lirae between them; fine spirals continue across base and onto anterior canal, the extremity of which is missing. Outer lip of aperture broken, with remnant of posterior canal present.

\section{Dimensions}

$\begin{array}{cccc} & \text { Height } & \text { Max. diameter } & \text { No. whorls } \\ \text { WAM 06.191 } & 16.5^{*} & 6.1 & \text { ca } 8 \\ \text { *anterior canal broken } & & \end{array}$

\section{Remarks}

No congenor similar to this specimen from Kalbarri is known from the Eocene of southern Australia. The species has some resemblance to some Recent Indo-Southwest Pacific species of Gemmula such as G. speciosa (Reeve, 1833) and $G$. kieneri (Doumet, 1840).

\section{Occurrence}

Southern Carnarvon Basin: unnamed sandstone, Middle-Late Eocene.

\section{Genus Mauidrillia Powell, 1942}

\section{Mauidrillia sp. cf. M. aldingensis Powell, 1944} Figure 3.4

Mauidrillia aldingensis Powell, 1944: 36, plate 4, figure 6.

\section{Material examined}

Australia: Western Australia: Kalbarri National Park, ca. $19.5 \mathrm{~km}$ ESE. of Kalbarri: 1 specimen (WAM 07.30).

\section{Description}

Shell small, fusiform with convex, weakly shouldered whorls; protoconch domed, smooth, of
1.5 whorls, slightly deviated; first teleoconch whorl with close, axial costellae, gradually becoming spaced to form low, rounded, axial costae of unequal prominence and confined to abapical portion of whorl; aperture with stronger varix; axials overlain by fine spiral lirae, ca 10 on penultimate whorl and extending (last whorl) onto anterior canal; a weak, subsutural spiral present between costae and adapical suture; aperture broken, columella smooth with weak parietal callosity; tip of anterior canal broken.

\section{Dimensions}

$\begin{array}{lccc} & \text { Height } & \text { Max. diameter } & \text { No. whorls } \\ \text { WAM 07.30 } & 7.4 & 3.1 & 6.3\end{array}$

\section{Remarks}

The single specimen in the study material has somewhat more tumid whorls and a more elongate canal, compared with topotypes of Mauidrillia aldingensis from the Blanche Point Formation of the St Vincent Basin. No congenor is as yet known from the Pallinup Formation of the Bremer Basin.

\section{Occurrence}

Southern Carnarvon Basin: unnamed sandstone, Middle-Late Eocene.

\section{Family Marginellidae}

\section{Genus Marginella Lamarck, 1799}

\section{Remarks}

The few specimens of this family and genus and their inferior preservation inhibit detailed comparison with taxa from other Australian Eocene sources, except to observe that somewhat similar specimens, all awaiting study, have been collected from the Pallinup Formation, Bremer Basin.

\section{Marginella sp. A}

Figure 3.6

\section{Material examined}

Australia: Western Australia: Kalbarri National Park, ca. $19.5 \mathrm{~km}$ ESE. of Kalbarri: 1 specimen (WAM 04.224); 1 specimen (WAM 07.136); 1 specimen (NMV P314039). Total of three specimens.

\section{Description}

Shell biconic, spire elevated, tapered anteriorly; four strong, oblique, columellar plaits. Aperture and much of last whorl missing.

\section{Dimensions}

WAM 04.224

Height Max. diameter




\section{Remarks}

Specimen WAM 07.136 has four oblique, columellar plaits and a small, fifth horizontal plait. This species is rather more ventricose than Marginella sp. B.

\section{Occurrence}

Southern Carnarvon Basin: unnamed silicified sandstone, Middle-Late Eocene.

\section{Marginella sp. B}

Figure 3.7

Material examined

Australia: Western Australia: Kalbarri National Park, ca. 19.5 km ESE. of Kalbarri: 1 specimen (WAM 05.195).

\section{Description}

Shell subcylindrical with short spire and bluntly rounded apex; two strong, anteriorly located, oblique columellar plaits; inner lip (aperture) finely denticulate.

\section{Dimensions}

WAM 05.195

$$
\begin{array}{cc}
\text { Height } & \text { Max. diameter } \\
5.7 & 2.3
\end{array}
$$

\section{Remarks}

This species is relatively elongate and subcylindrical compared with Marginella sp. A.

\section{Occurrence}

Southern Carnarvon Basin: unnamed sandstone, Middle-Late Eocene.

\section{Family Mitridae}

\section{Remarks}

No generic assignment is attempted for two species of this family represented in the study material, pending the collection of further specimens.

\section{Mitrid, sp. A}

Figure 3.24

\section{Material examined}

Australia: Western Australia: Kalbarri National Park, ca. 19.5 km ESE. of Kalbarri: 1 fragmentary specimen (WAM 05.194).

\section{Description}

A fragmentary shell of mitrid form, retaining the apical five whorls and part of the sixth. Protoconch large, paucispiral, of 1.1 whorls, the tip immersed.
First teleoconch whorl convex, smooth, developing weak, low, axial costellae and subsequently fine, close, spiral threads extending from suture to suture; axials remain low, weak, of irregular strength and spacing; columella with four strong spiral plaits, ascending within.

\section{Dimensions}

$\begin{array}{lccc} & \text { Height } & \text { Max. diameter } & \text { No. whorls } \\ \text { WAM 05.194 } & 9.8 & 6.1 & 6 \\ \text { Specimen fragmentary } & & \end{array}$

\section{Remarks}

What remains of this otherwise well-preserved specimen suggests a superficial resemblance to species of the genus Eumitra Tate, 1889. There are no known taxa elsewhere in the Australian Eocene similar to the present species. Differs from the associated Mitrid sp. B in its narrower spire, sculptured whorls and stronger plaits.

\section{Occurrence}

Southern Carnarvon Basin: unnamed sandstone, Middle-Late Eocene.

\section{Mitrid, sp. B \\ Figure 3.26}

\section{Material examined}

Australia: Western Australia: Kalbarri National Park, ca. $19.5 \mathrm{~km}$ ESE. of Kalbarri: 1 specimen (WAM 07.28).

\section{Description}

Shell missing apical portion and apertural part of last whorl, including anterior canal; partially encrusted with secondary silica. Spire about equal to half height, whorls slightly convex and slightly stepped at suture, without evident axial or spiral sculpture; columella with four weak, spaced, low, rounded plaits, callosity low, weak.

\section{Dimensions}

$\begin{array}{ccc} & \text { Height } & \text { Max. diameter } \\ \text { WAM 07.28 } & 36.3 & 13.3 \\ \text { Specimen broken } & \end{array}$

\section{Remarks}

Differs from the associated Mitrid sp. A in its greater diameter relative to height, absence of sculpture and weak, spaced columellar plaits. There is no taxon at present known similar to this from the Australian Eocene.

\section{Occurrence}

Southern Carnarvon Basin: unnamed sandstone, Middle-Late Eocene. 
Family Conidae

\section{Genus Conus Linnaeus, 1758}

Conus? sp.

Figure 2.22

\section{Material examined}

Australia: Western Australia: Kalbarri National Park, ca. $19.5 \mathrm{~km}$ ESE. of Kalbarri: 1 specimen (WAM 05.199).

\section{Description}

Internal mould of a low-spired, biconic shell retaining a few shell remnants of last whorl, partly overlain by secondary silica; columella smooth; apparent low spiral sculpture visible on last whorl through silica overlay.

\section{Dimensions}

WAM 05.199

$\begin{array}{cc}\text { Height } & \text { Max. diameter } \\ 16.4 & 12.0\end{array}$

\section{Remarks}

Generic identity of this specimen derives from the biconic shape of the internal mould and the absence of any trace of columellar plaits. An unidentified species of Conus, currently awaiting study, has been collected from the Pallinup Formation (Bremer Basin). Its relationship to the present species is unclear. No species of Conus is known from the Eocene of southeastern Australia.

\section{Occurrence}

Southern Carnarvon Basin: unnamed sandstone, Middle-Late Eocene.

\section{Genus Conorbis Swainson, 1840}

\section{Conorbis sp.}

Figures $3.21,3.22$

\section{Material examined}

Australia: Western Australia: Kalbarri National Park, ca. $19.5 \mathrm{~km}$ ESE. of Kalbarri: 1 specimen (WAM 07.29).

\section{Description}

Shell of medium size for genus, lacking apical and anterior extremities and apertural outer lip. Biconic, whorls slightly convex, weakly shouldered at mid-whorl and slightly recessed sutures; anterior canal (broken) probably a little attenuated. Sculpture fine, spiral only, concentrated below sutures; on last whorl, mostly on anterior half, continuous onto canal and across columella and parietal area. Aperture elongate, outer lip broken.

\section{Dimensions}

$\begin{array}{cccc} & \text { Height } & \text { Max. diameter } & \text { No. whorls } \\ \text { WAM 07.29 } & 18.5 & 8.1 & 3+ \\ \text { Specimen broken } & & \end{array}$

\section{Remarks}

Species of Conorbis are known from the Late Eocene of Victoria and South Australia (Long, 1981). The present specimen, though poorly preserved, is unlike these, having a slightly attenuated canal and a slight shoulder to the whorls. No congener is as yet known from the Pallinup Formation.

\section{Occurrence}

Southern Carnarvon Basin: unnamed sandstone, Middle-Late Eocene.

\section{ACKNOWLEDGEMENTS}

We are grateful to Mr David Barton of Kalbarri for presentation of his fossil collection to the Western Australian Museum. Mrs J. Bevan, Curator of the Geological Museum, School of Earth and Geographical Sciences, The University of Western Australia, kindly loaned specimens. Mrs L.M. Marsh, Western Australian Museum, provided advice regarding coral identifications and ecology. Mr David Holloway and Mr Rolf Schmidt, Museum Victoria, provided advice on preparing the illustrations. Dr Alan Beu and Associate Professor David Haig suggested useful emendations to the original manuscript. Dr John Long facilitated TAD's visit to Western Australia. Support from the Western Australian Department of Environment and Conservation is acknowledged with appreciation. Ms G. Harsa prepared the typescript.

\section{REFERENCES}

Berggren, W.A. and Miller, K. G. (1988). Paleogene tropical planktonic foraminiferal biostratigraphy and magnetobiochronology. Micropaleontology 34: 362380.

Beu, A.G. (2006). Marine Mollusca of oxygen isotope stages of the last 2 million years in New Zealand. Part 2. Biostratigraphically useful and new Pliocene to Recent bivalves. Journal of the Royal Society of New Zealand 36: 151-338.

Beu, A.G. and Darragh, T.A. (2001). Revision of southern Australian Cenozoic fossil Pectinidae (Mollusca: Bivalvia). Proceedings of the Royal Society of Victoria 113: 1-205.

Beu, A. G. and Maxwell, P. A. (1990). Cenozoic Mollusca of New Zealand. New Zealand Geological Survey Paleontological Bulletin 58: 1-518.

Blevins, J. (2001). Nhanda. An Aboriginal language of Western Australia. Oceanic Linguistics Special Publication 30: 1-170. University of Hawaii Press: Honolulu. 
Cairns, S.D. (1998). Azooxanthellate Scleractinia (Cnidaria: Anthozoa) of Western Australia. Records of the Western Australian Museum 18: 361-417.

Cairns, S.D. and Parker, S.A. (1992). Review of the Recent Scleractinia (stony corals) of South Australia, Victoria and Tasmania. Records of the South Australian Museum, Monograph Series 3: 1-82.

Chapman, F. and Crespin, I. (1934). The palaeontology of the Plantagenet Beds of Western Australia. Journal of the Royal Society of Western Australia 20: 103-136.

Cockbain, A.E. (1981). On the age of the Merlinleigh Sandstone, Carnarvon Basin. Annual Report of the Geological Survey of Western Australia for 1980: 4446.

Condon, M.A. (1968). The geology of the Carnarvon Basin, Western Australia. Part 3. Post-Permian stratigraphy; structure, economic geology. Bureau of Mineral Resources, Geology and Geophysics Bulletin 77.

Cossmann, M. (1920). Rectifications de nomenclature. Revue Critique de Paléozoologie 24: 36-38.

Darragh, T.A. (1985). Molluscan biogeography and biostratigraphy of the Tertiary of southeastern Australia. Alcheringa 9: 83-116.

Darragh, T.A. (1989). A revision of the Tertiary Volutidae (Mollusca: Gastropoda) of south-eastern Australia. Memoirs of the Museum of Victoria 49: 195-307.

Darragh, T.A. and Kendrick, G.W (1980). Eocene bivalves from the Pallinup Siltstone near Walpole, Western Australia. Journal of the Royal Society of Western Australia 63: 5-20.

Darragh, T.A. and Kendrick, G.W. (2000). Eocene bivalves and gastropods from the Pallinup Siltstone, Western Australia, with new records from the Eocene and Oligocene of southeastern Australia. Proceedings of the Royal Society of Victoria 112: 17-58.

Haig, D.W. and Mory, A.J. (2003). New record of siliceous, marine later Eocene from Kalbarri, Western Australia. Journal of the Royal Society of Western Australia 86: 107-113.

Haig, D. W., Smith, M. and Apthorpe, M. C. (1997). Middle Eocene Foraminifera from the type Giralia Calcarenite, Gascoyne Platform, Southern Carnarvon Basin, Western Australia. Alcheringa 21: 229-245.

Harris, G.F. (1897). Catalogue of Tertiary Mollusca in the Department of Geology, British Museum (Natural History). Part 1. The Australian Tertiary Mollusca. British Museum (Natural History); London.

Houbrick, R.S. (1992). Monograph of the genus Cerithium Bruguière in the Indo-Pacific. Smithsonian Contributions to Zoology 510: 1-211.

Landman, N.H., Rye, D.M. and Shelton, K.L. (1983). Early ontology of Eutrephoceras compared to Recent Nautilus and Mesozoic ammonites: evidence from shell morphology and light stable isotopes. Paleontology 9: 269-279.

Long, D.C. (1981). Late Eocene and Early Oligocene Turridae (Gastropoda: Prosobranchiata) of the Browns Creek and Glen Aire Clays, Victoria, Australia. Memoirs of the National Museum of Victoria 42: 15-55.

Ludbrook, N.H. (1956). The molluscan fauna of the Pliocene strata underlying the Adelaide Plains. Part
III. Scaphopoda, Polyplacophora, Gastropoda (Haliotidae to Tornidae). Transactions of the Royal Society of South Australia 79: 1-36.

Ludbrook, N.H. (1961). Revision of the Tate molluscan types: Pelecypoda-Nuculidae and Nuculanidae. Transactions of the Royal Society of South Australia 85: 55-65.

Ludbrook, N.H. (1973). Distribution and stratigraphic utility of Cenozoic molluscan faunas in southern Australia. Tohoku University Science Reports, Second Series (Geology), Special Volume 6, Hatai. Memorial Volume: 241-261.

Marwick, J. (1938). Notocallista and its allies. Transactions of the Royal Society of New Zealand 68: 60-81.

Marwick, J. (1971). New Zealand Turritellidae related to Zeacolpus Finlay (Gastropoda). New Zealand Geological Survey, Palaeontological Bulletin 44.

Matsukuma, A. (1996). A new genus and four new species of Chamidae (Mollusca, Bivalvia) from the Indo-West Pacific with reference to transposed shells. Bulletin du Muséum national d'Histoire naturelle, Paris 4e sér. 18: 23-53.

Matsukuma, A., Hamada, N. and Scott, P.H. (1997). Chama pulchella (Bivalvia: Heterodonta) with transposed shell and normal dentition. Venus 56: 221-231.

Maxwell, P. A. (1969). Middle Tertiary Mollusca from North Otago and South Canterbury, New Zealand, with a review of New Zealand species of Venericardia (Carditidae, Pelecypoda). Transactions of the Royal Society of New Zealand. Geology 6: 155-185.

McGowran, B. (1959). Tertiary nautiloids (Eutrephoceras and Cimomia) from South Australia. Journal of Paleontology 33: 435-448.

McGowran, B., Archer, M., Bock, P., Darragh, T.A., Godthelp, H., Hageman, S., Han, S.J., Hill, R., Li, Q., Maxwell, P.A., McNamara, K.J., Macphail, M., Mildenhall, D., Partridge, A.D., Richardson, J., Shafik, S., Truswell, E.M. and Warne, M. (2000). Australasian palaeobiogeography: the Palaeogene and Neogene record. Memoir of the Association of Australasian Palaeontologists 23: 405-470.

McNamara, K.J. and Scott, J.K. (1983). A new species of Banksia from the Eocene Merlinleigh Sandstone of the Kennedy Range, Western Australia. Alcheringa 7: 185-193.

Powell, A.W.D. (1944). The Australian Tertiary Mollusca of the family Turridae. Records of the Auckland Institute and Museum 3: 3-68.

Singleton, F.A. (1932). Studies in Australian Tertiary Mollusca. Part 1. Proceedings of the Royal Society of Victoria 44: 289-308.

Tate, R. (1886). The lamellibranchs of the Older Tertiary of Australia. Part I. Journal and Proceedings of the Royal Society of South Australia 8: 96-158.

Tate, R. (1887). The lamellibranchs of the Older Tertiary of Australia. Part II. Transactions of the Royal Society of South Australia 9: 142-189.

Tate, R. (1888). The gastropods of the Older Tertiary of Australia. Part I. Transactions of the Royal Society of South Australia 10: 91-176. 
Tate, R. (1889). The gastropods of the Older Tertiary of Australia. Part II. Transactions of the Royal Society of South Australia 11: 116-147.

Tate, R. (1890). The gastropods of the Older Tertiary of Australia. Part III. Transactions of the Royal Society of South Australia 13: 185-235.

Tate, R. (1892). Nine plates illustrative of Professor Tate's paper on the Gasteropoda of the Tertiary of Australia - Part 3 in Volume 13 of the Society's Transactions. Transactions of the Royal Society of South Australia 15: Plates 5-13.

Teichert, C. (1944). The genus Aturia in the Tertiary of Australia. Journal of Paleontology 18: 73-82.

Teichert, C. (1947). Notes on Eocene nautiloids from Victoria. Mining and Geological Journal 3(1): 40-43.

Manuscript accepted 5 October 2007. 